Universidade de Brasília

Centro de Excelência em Turismo

\title{
SEGURANÇA NO TRABALHO EM UNIDADES DE ALIMENTAÇÃO E NUTRIÇÃO - TREINAMENTOS E DINÂMICAS
}

Maria Goreti Vaz Tostes

Raquel Assunção Botelho (orientadora)

Karin Eleonora Sávio de Oliveira (co-orientadora)

Monografia apresentada ao Centro de Excelência em Turismo da Universidade de Brasília como requisito parcial para obtenção do certificado de Especialista em Qualidade em Alimentos

Brasília, DF, Janeiro de 2003 


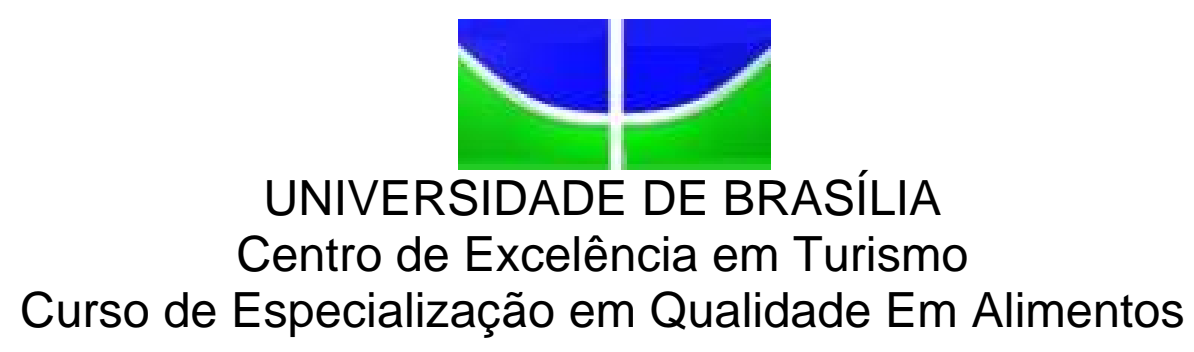

\section{SEGURANÇA NO TRABALHO EM UNIDADES DE ALIMENTAÇÃO E NUTRIÇÃO - TREINAMENTOS E DINÂMICAS}

Maria Goreti Vaz Tostes

Banca Examinadora

Raquel Assunção Botelho, MS

Orientadora

Karin Eleonora Sávio de Oliveira, MS

Membro da Banca

Domingos Sávio Spezia, MS

Membro da Banca

Brasília, DF, Janeiro de 2003. 
Tostes, Maria G. V.

Segurança no trabalho em Unidades de Alimentação e Nutrição - Treinamentos e Dinâmicas/ Maria Goreti Vaz Tostes.

$76 \mathrm{p}$.

Monografia (especialização) - Universidade de Brasília. Centro de Excelência em Turismo. Brasília, 2003.

Área de concentração: Nutrição

Orientadora: Raquel Assunção Botelho.

1.Segurança .2. Unidades de Alimentação

3.

Treinamento. 4. Saúde .- Monografia 


\section{Maria Goreti Vaz Tostes}

\section{SEGURANÇA NO TRABALHO EM UNIDADES DE ALIMENTAÇÃO E NUTRIÇÃO - TREINAMENTOS E DINÂMICAS}

Comissão Avaliadora

Raquel Assunção Botelho, MS

Karin Eleonora Sávio de Oliveira, MS

Domingos Sávio Spezia, MS

Brasília, DF, 20 de janeiro de 2003. 


\section{AGRADECIMENTOS}

À Fundação de Empreendimentos Científicos e Tecnológicos, pelo apoio e incentivo para a realização desse trabalho;

Aos operadores da Unidade de Alimentação e Nutrição, que através da análise sistemática da rotina laboral, possibilitou demonstrar a importância do estudo desenvolvido através deste trabalho;

À Professora Raquel Assunção Botelho, pela orientação e colaboração durante o desenvolvimento deste trabalho;

À Professora Karin E. Sávio de Oliveira, por contribuir para o desenvolvimento desse trabalho. 
"A verdadeira questão não é o que se gasta, mas, sim, quanto uma pessoa não treinada custa para a corporação."

Motorolla 


\section{RESUMO}

Segurança e saúde são imprescindíveis quando o propósito é manter o ambiente hígido e produtivo. A conscientização e a capacitação dos trabalhadores é o ponto primordial para evitar acidentes no trabalho. $O$ presente estudo objetiva analisar a inserção do tema Segurança do Trabalho nas atividades realizadas em Unidades de Alimentação e Produção (UAN) e propor treinamentos, a serem aplicados nas UAN, sobre temas na área de Segurança no Trabalho. O referencial teórico selecionado dá ênfase na importância do trabalho com segurança, onde são abordados temas como acidente de trabalho, Equipamento de Proteção Coletiva (EPC) e Equipamento de Proteção Individual (EPI), Doenças Osteomusculares Relacionadas ao Trabalho (DORT) e ergonomia. Esse trabalho foi desenvolvido através de pesquisa exploratória, na forma de referência bibliográfica. Os treinamentos propostos foram desenvolvidos na forma de metodologia participativa e dialógica, enfatizando a relação entre a fundamentação teórica e a prática diária nas UAN. Nos treinamentos propostos foram priorizadas a utilização de dinâmicas de grupo e outras dinâmicas, objetivando o melhor entendimento e participação dos funcionários. Quando um perigo não pode ser eliminado ou neutralizado por interferência direta no processo, a prevenção dependerá, exclusivamente do comportamento das pessoas. Essa é uma situação que fragiliza a eficácia de um Programa de Prevenção de Acidentes. Condições como essas recomendam a adoção do 'hábito de trabalho seguro'. É nesse ponto, que um programa de treinamento constante para os funcionários, faz-se necessário para garantir que a política de segurança seja mantida e disseminada dentro de empresa.

Segurança; Unidade de Alimentação; Treinamento. 


\section{ABSTRACT}

Security and health are very important factors when the purpose is to maintain a productive and healthy environment. Workers awareness and preparation is a fundamental aspect to avoid accidents at work. The present study has the objective to analyse the inclusion of work security activities in Food Service Units and to propose trainings to be executed in the units. The theorical reference emphasizes the importance of working safely dealing with subjects related to work accident, Collective Protection Equipment and Individual Protection Equipment, muscle disorders related to work and ergonomy. This work was developed through exploratory research. The proposed trainings were designed in the form of a participative methodology, emphasizing the relation between the theory and the daily practice in Food Service Units. In the proposed trainings, the aim was the use of dynamic group activities that had the objective of a better understanding and participation of the workers. When a danger can not be eliminated or neutralized by direct interference in the process, prevention will depend exclusively on people's behavior. This situation fragilizes the effectiveness of the Accident Prevention Program. These conditions recommend adaptation of work safe habits. In this way, o constant training program for workers is necessary to maintain the security policy in the company.

Security; Food Service Units; Training. 


\section{SUMÁRIO}

1 - INTRODUÇÂO

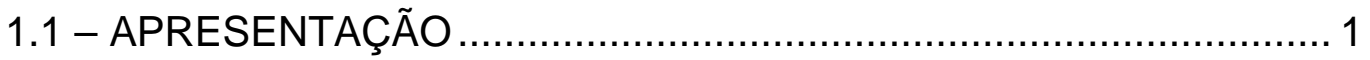

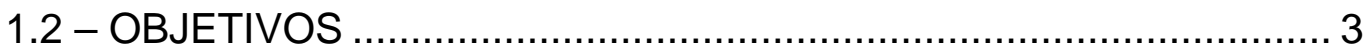

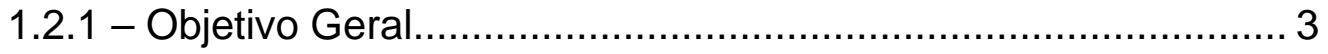

1.2.2 - Objetivos Específicos …………....................................... 3

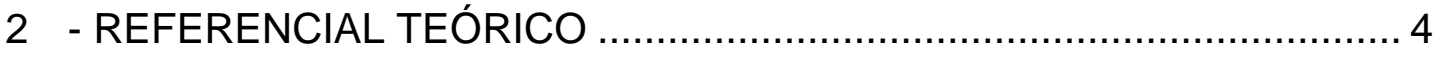

2.1 - CONDIÇÃO DE TRABALHO.................................................... 4

2.1.1 - Aspectos Legais da Condição de Trabalho ………………... 5

2.1.2 - Acidentes e Doenças Profissionais: Caracterização e

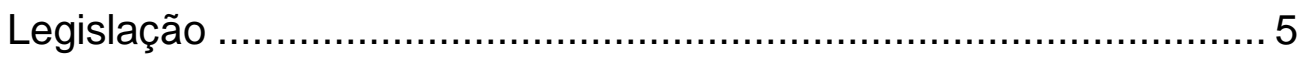

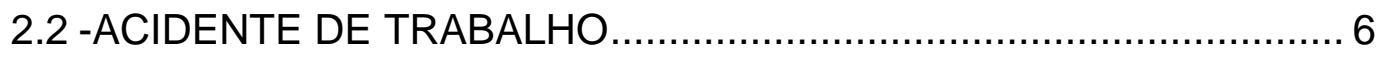

2.2.1 - Conceito e Aplicação ………………………………….... 6

2.2.2 - Riscos Ambientais ............................................................... 7

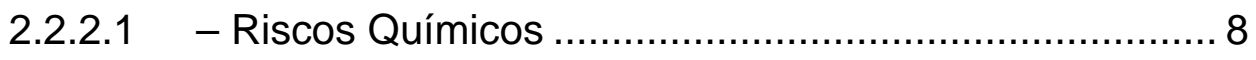

2.2.2.2 - Riscos Biológicos ………………………............ 9

2.2.2.3 - Riscos Físicos ................................................... 10

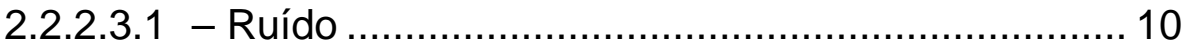

2.2.2.3.2 - Temperatura ................................................ 12

2.2.2.3.3 - Riscos Mecânicos ............................................... 14

2.2.3 - Medição dos Riscos Ambientais ........................................ 15

2.2.3.1 - Programa de Prevenção dos Riscos Ambientais ...... 15

2.2.3.2 - Programa de Controle Médico Saúde Ocupacional .. 15 
2.4 - EQUIPAMENTO DE PROTEÇÃO INDIVIDUAL .......................... 17

2.5 - DISTÚRBIOS OSTEOMUSCULARES RELACIONADOS

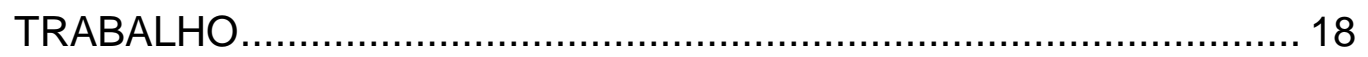

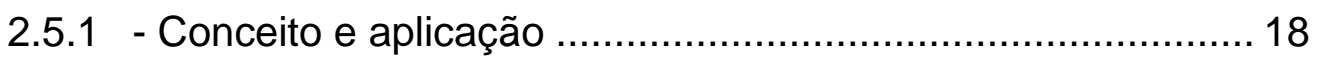

2.5.2 - Tratamento e Reabilitação.................................................. 22

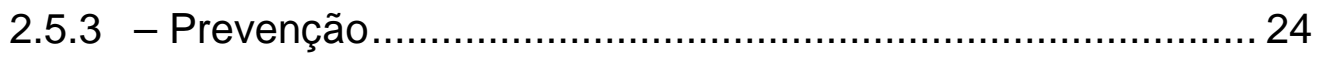

2.5.3.1 - Metas de Prevenção ............................................... 25

2.5.3.2 -Como Prevenir ...................................................... 26

2.5.3.2.1 - Alternância das Tarefas e Rotação nos Postos

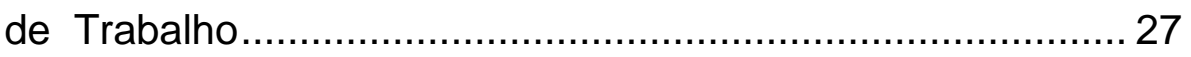

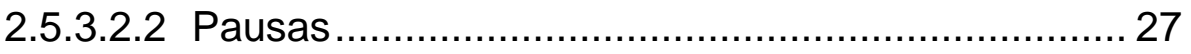

2.5.3.2.3 - Redução na Jornada de Trabalho ……………... 27

2.5.3.2.4 - Revisão da Produtividade e das Formas de

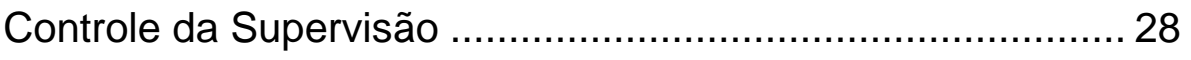

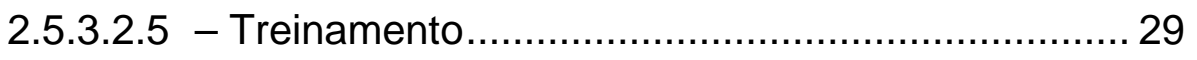

2.5.3.2.6 - Acompanhamento Trabalhadores Acometidos .... 29

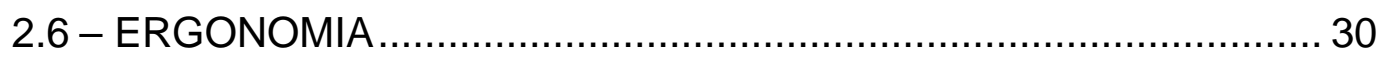

2.6.1 - Conceito e Aplicação .......................................................... 30

2.6.2 - Análise Ergonômica do Trabalho ......................................... 32

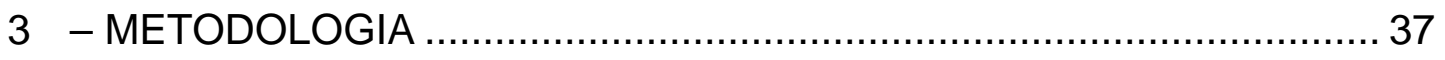

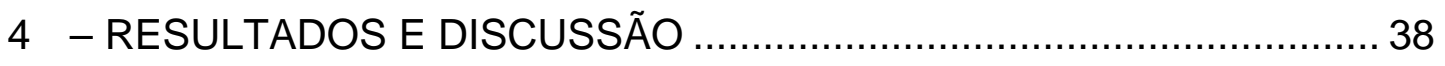

4.1 - TREINAMENTOS - A ARTE DE APRENDER UM NOVO HÁBITO .... 38

4.1.1 - Treinamento I - Acidente de Trabalho ………..................................... 39 
4.1.2 - Treinamento II - Equipamento de Proteção Coletiva

(EPC) e Equipamento de Proteção Individual (EPI)

4.1.3 - Treinamento III - Lesões por Esforços Repetitivos (LER)

Doenças Osteomusculares Relacionadas ao Trabalho (DORT) 44

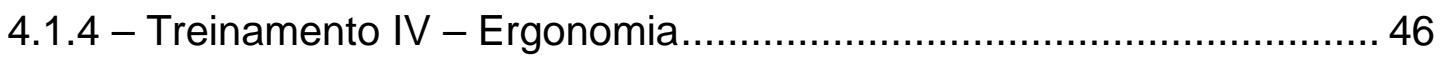

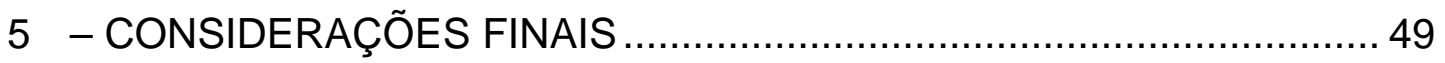

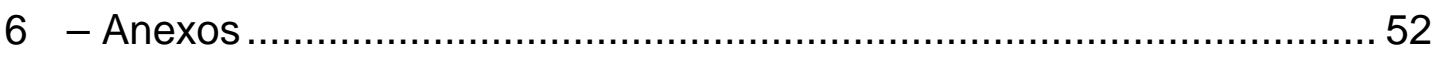

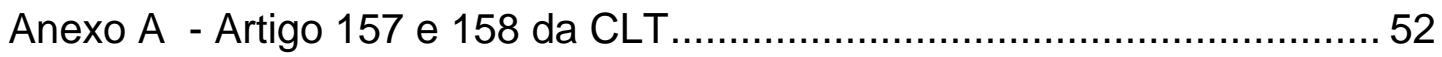

Anexo B - Lei 8.213 - Benefícios da Previdência Social ............................. 53

Anexo C - Limites de Tolerância para Ruído (NR-15) ................................. 55

Anexo D - Dinâmica de Grupo - Balões Coloridos ........................................ 56

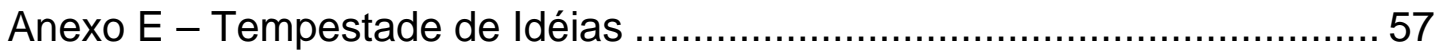

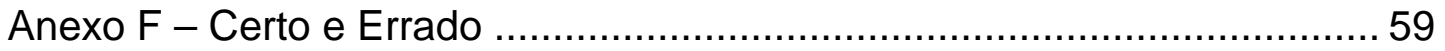

Anexo G - Dinâmica de Grupo - Cosme e Damião ...................................... 60

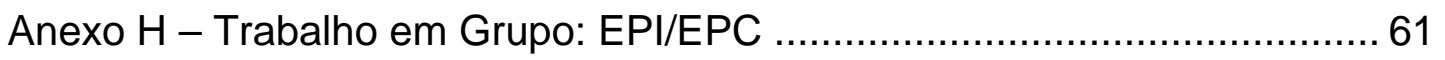

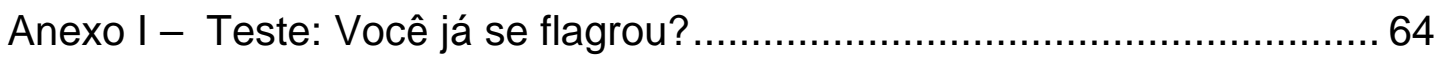

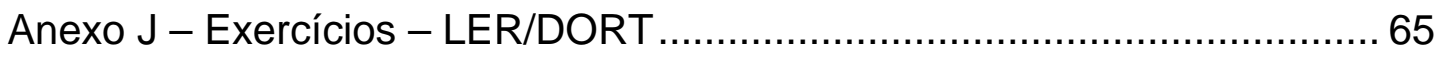

Anexo K - Dinâmica de Grupo - Rabo do Burro.......................................... 68

Anexo L - Dinâmica de Grupo - Linha da Vida.......................................... 70

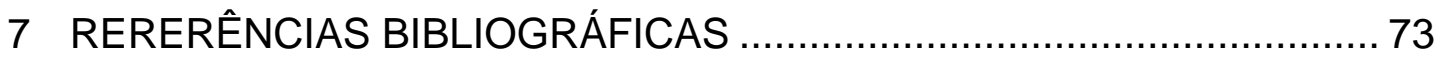




\section{CAPITULO I}

\subsection{INTRODUÇÃO}

Durante muito tempo, o tema de como os trabalhadores adoeciam e morriam em conseqüência do trabalho foi considerado irrelevante, comparado aos resultados obtidos em termos de produtividade e competitividade no mercado.

Essa situação era de tal forma disseminada, que mesmo os trabalhadores em suas organizações sindicais, em vez de lutarem por suas vidas, criaram os movimentos e processos por adicionais de insalubridade, priorizando a remuneração ao invés da saúde.

Atualmente esses pensamentos vêm mudando. Se antes, sugar ao máximo a força de trabalho dos trabalhadores era considerada a melhor forma de se obter bons resultados nas finanças das empresas, atualmente entram em jogo aspectos éticos que acabam influenciando nos resultados finais.

Essa empresa acaba perdendo, no ponto de vista de mercado, em relação sua imagem e provavelmente à sua rentabilidade.

Ao se conceber uma empresa, existe uma multiplicidade de ações e decisões que se deve tomar, caindo no esquecimento muitas vezes a atenção necessária quanto ao ambiente de trabalho que oferece aos seus funcionários.

Em sua formação, as pessoas que atuam em cargos de gerenciamento, raramente tem acesso a informações que demonstrem a importância das condições de trabalho para a satisfação e manutenção da saúde dos trabalhadores e do meio ambiente, para a melhoria da produtividade da empresa e, por conseguinte, da competitividade desta.

A não compreensão desse relacionamento leva, sem dúvida, a perdas maiores que os investimentos requeridos para adequar o local de trabalho a padrões mínimos de conforto e segurança.

O gerenciamento das pessoas e do sistema produtivo no tocante à segurança e saúde de trabalhador, faz parte de um complexo de atividades que se inicia no projeto do produto, passando pela escolha dos materiais que serão utilizados, pelo desenho da produção propriamente dito, com a elaboração de 
planos de produção, escolha de maquinarias e determinação dos requisitos dos indivíduos que executarão determinadas tarefas e demais requisitos para obtenção dessa produção, como a escolha dos grupos de trabalho, a elaboração do jornadas e dos turnos, até a obtenção do produto final da empresa.

Apesar da aparente complexidade de se coordenar todas as atividades operacionais da organização e realizá-las adequadamente, sem, contudo, descuidar da questão da segurança, isso pode tornar-se algo extremamente simples. Uma vez inseridos no cotidiano da empresa, por meio de uma conduta proativa, as atribuições adicionais de cada pessoa não terão significativo impacto sobre sua carga de trabalho, uma vez que os hábitos desenvolvidos e portanto, assumidos por cada indivíduo contemplarão, necessariamente, a cota de responsabilidade que cabe a cada um destes no estabelecimento do modelo de gestão voltado à segurança coletiva.

A compreensão de que a gestão da segurança é uma atividade coletiva e que, dessa forma, deve ser exercida e realizada, é o passo inicial para que a implementação desse projeto alcance o sucesso esperado.

A conscientização e a capacitação dos trabalhadores, para que possam reconhecer as possibilidades de riscos, propiciarão as condições mínimas necessárias para que possam colaborar ativamente na condução do gerenciamento do ambiente em que estão inseridos.

Assumir, erroneamente, que somente os profissionais especializados, como: técnicos e engenheiros de segurança, médicos do trabalho, devem atuar no gerenciamento do sistema produtivo no tocante à questão da segurança é assumir que, em última análise, estamos colocando nossa vida à mercê da consciência e da capacidade profissional de outras pessoas. Não parece ser boa medida entregarmos nosso destino a profissionais supostamente habilitados e qualificados para a importante missão de que os incumbimos, com plena e irrestrita confiança pelo fato de preferimos eximir-nos da própria responsabilidade que nos compete. 


\subsection{OBJETIVOS}

\subsubsection{Objetivo Geral}

O objetivo desta monografia é discutir e analisar a inserção do tema Segurança do Trabalho nas atividades realizadas por profissionais em Unidades de Alimentação e Nutrição (UAN).

\subsubsection{Objetivos Específicos}

Propor treinamentos, a serem aplicados nas UAN, sobre temas na área de Segurança no Trabalho.

Alertar os funcionários da UAN quanto aos riscos de acidentes de trabalho a que estão expostos e informar sobre formas de prevenção à acidentes.

Demonstrar a importância da adoção e utilização correta de EPC (Equipamento de Proteção Coletiva) e EPI (Equipamento de Proteção Individual) para a diminuição da exposição à agentes ambientais presentes nas UAN.

Propor adoção de política prevencionista para LER/DORT (Lesões por Esforços Repetitivos, atualmente conhecida como Distúrbios Osteomusculares Relacionados ao Trabalho).

Preparar os funcionários da UAN para realizar suas tarefas de maneira ergonomicamente correta. 


\section{CAPÍTULO II - REFERENCIAL TEÓRICO}

\subsection{CONDIÇÃO DE TRABALHO}

Segundo estudo realizado pelo Ministério de Previdência e Assistência Social, o Brasil ocupa o $4^{\circ}$ lugar no ranking de maior número de acidentes ocorridos no trabalho. Entre 1971 e 2002, morreram mais de 120 mil pessoas e outras 300 mil ficaram inválidas devido a esses acidentes.

"No Brasil, ocorrem mais de 400 mil acidentes de trabalho por ano, sendo que quase 3.800 são fatais. Além disso, ocorrem cerca de 28 mil casos de doenças profissionais. Esses números são muito subestimados. Calcula-se que $80 \%$ dos acidentes e doenças profissionais no mercado de trabalho formal, especialmente, os de menor gravidade, não são notificados. Além disso, 57\% da força de trabalho no Brasil trabalham na informalidade, sem registro em carteira de trabalho, sem vínculo com a seguridade social e, portanto, fora do sistema de notificação." (Pastore, 2001)

Somente os trabalhadores com vínculo empregatício formal e que contribuem para a previdência social têm direito ao pagamento de benefícios originados do acidente de trabalho.

Segurança e saúde são imprescindíveis quando o propósito é manter o ambiente hígido e produtivo. Tais questões estão diretamente ligados à valorização do elemento humano como primordial para o sucesso de qualquer organização. (Piza, 1997)

Vive-se em um mundo em que, a cada dia, são crescentes as descobertas e inovações tecnológicas, a disseminação de informações sobre formas de prevenção de acidentes e doenças do trabalho se torna decisiva para que a qualidade de vida laboral seja valorizada. $O$ trabalho educativo dentro das empresas permite que haja cada vez mais trabalhadores e empresários conscientes da importância da Saúde e Segurança no Trabalho.

Considerando sua grande responsabilidade social, é indispensável que a indústria brasileira e demais setores de mercado, se preocupem com a 
promoção de iniciativas que possibilitem a redução de problemas de tal gravidade.

\subsection{1 - Aspectos Legais das Condição de Trabalho}

Quando discute-se sobre condição de trabalho e meio ambiente, trata-se de saúde individual e coletiva. A compreensão dos mecanismos e o tratamento dado aos impactos causados sobre eles devem ser estendidos às famílias e, inegavelmente, às gerações futuras.

"A empresa que melhor protege o trabalhador não é aquela que the oferece melhores meios de proteção e sim aquela que menos o expõe a riscos ou que menos oferece possibilidades de danos à sua saúde e integridade". (Piza, 2001)

Submeter uma pessoa a executar atividades sob condições de trabalho inadequadas que tragam prejuízos, imediatos ou futuros, a saúde dela, em qualquer duração de jornada ou tipologia de tarefa, vem de encontro ao artigo $1^{\circ}$ da Constituição Federal de 1988 (CF/88), constituindo-se, dessa forma, em algo que deveria ser prontamente rejeitado por todos os cidadãos, sejam eles trabalhadores ou empregadores. Ainda na CF/88, no Capítulo II do Título II, são estabelecidos os direitos do cidadão brasileiro, destacando-se os direitos à saúde, à segurança e à previdência social. Entre os direitos, deve ser observada a redução dos riscos inerentes ao trabalho, por meio de normas de saúde, higiene e segurança (inciso XXII).

No artigo 157 da Consolidação das Leis Trabalhistas (CLT) são estabelecidas as competências da empresas e no artigo 158 às atribuições aos trabalhadores no que se refere a prevenção a acidentes de trabalho, que devem ser seguidas em todas as esferas de trabalho no Brasil. (Anexo A)

\subsection{2 - Acidentes e Doenças Profissionais: Caracterização e Legislação}

Apesar da grande quantidade de legislação que trata da questão do trabalhador no Brasil, ainda são muito reduzidos o interesse e o conhecimento do cidadão comum acerca da temática. 
A Lei número 8.213, que trata dos benefícios da Previdência Social, estabelece em seus artigos 19, 20 e 21 os conceitos de acidente de trabalho e doenças profissionais. (Anexo B)

O acidente de trabalho tem como resultado uma resposta abrupta, a curto prazo, e, geralmente, associa danos pessoais e perdas materiais. Sua ocorrência torna-se, dessa forma mais aparente;

E a doença do trabalho apresenta na maioria dos casos uma resposta lenta. A médio e longo prazos, manifesta-se de forma insidiosa, sorrateiramente. Pode, portanto, resultar, pela ausência de sintomas aparentes em seus primeiros estágios, em sua detecção tardia. Daí a necessidade da guarda e conservação dos registros sobre a saúde dos empregados por prazos tão amplos.

Ambos são extremamente danosos às empresas. O acidente traz prejuízos imediatos; a doença trará prejuízos futuros.

Investir em condições de trabalho hoje significa minimizar as possibilidades de vir a organização a perder, hoje ou amanhã.

\subsection{ACIDENTE DE TRABALHO}

\subsubsection{Conceito e Aplicação}

Acidente de trabalho, segundo a Lei 8213, de 24 de julho de 1991 da Previdência Social, é o que acorre no exercício do trabalho a serviço da empresa ou pelo exercício do trabalho de segurados, provocando lesão corporal ou perturbação funcional que cause a morte ou a perda ou ainda redução permanente ou temporária da capacidade para o trabalho. Inclui nesses casos também a chamada doença profissional."(Piza, 1997)

No conceito técnico, o resultado do acidente não é fator preponderante para a prevenção, tendo em vista que, quando se perde não existirá mais prevenção. Restará apenas, correção. 
Como o objetivo técnico é o da prevenção e não o da correção tem-se como definição de acidente de trabalho todo fator negativo que interfira ou interrompa o andamento normal de uma atividade.

Dentro do conceito de Segurança do Trabalho a preocupação se estende a todas as ocorrências que interfiram em solução de continuidade em qualquer processo independente se dela tenha-se resultado lesão corporal, perda material, perda de tempo ou mesmo esses três fatores conjuntos.

"O trabalho em UAN tem sido caracterizado por movimentos repetitivos, levantamento de peso excessivo e permanência por períodos prolongados na postura em pé. Além disso, sofre a pressão temporal da produção, a qual necessita ajustar-se aos horários de distribuição das refeições, condicionando e/ou modificando constantemente o modo operatório dos operadores, a fim de atender a demanda."(Monteiro e col., 1997)

As deficiências de planejamento na concepção das UANs, conjugadas à falta de treinamento de pessoal, ao excesso de atividades, a problemas de manutenção e a despreocupação com a modernização dos equipamentos, acabam ocasionando ou agravando os problemas de saúde do operador e, até mesmo, causando acidentes de trabalho.

"No Brasil, frequentemente a produção de refeições exige dos operadores alta produtividade em tempo limitado, porém em condições inadequadas de trabalho, com problemas de ambiente, equipamentos e processos. Tais condições acabam levando a insatisfações, cansaço excessivo, queda de produtividade, problemas de saúde e acidente de trabalho." (Santana e col., 1996)

"Em estudo realizado em restaurantes da grande São Paulo, entre os anos de 1988 e 1998, a partir de 530 Comunicações de Acidentes de Trabalho (CATs), foi constatado que $57,5 \%$ dos acidentes ocorreram na cozinha. As principais categorias de acidentes foram queimaduras (45,8\%), seguidas por lesões osteomusculares (40,6\%), e outras (13,5\%). Em relação ao objeto causador, as CATs mostraram que 177 acidentes foram devidos à exposição do calor: objetos e óleos quentes." (Chamma e col., 1999) 


\subsection{2 - Riscos Ambientais}

Agentes ambientais ou riscos ambientais são os elementos ou substâncias presentes nos diversos ambientes humanos, que quando encontrados acima dos limites de tolerância, podem causar danos á saúde das pessoas.

A medicina do trabalho estuda os produtos existentes na empresa com o objetivo de avaliar o poder que esses possuem de contaminar ou provocar doenças nos trabalhadores.

São considerados riscos ambientais, os agentes físicos, químicos, biológicos, mecânicos e os agentes ergonômicos.

\subsubsection{1 - Riscos Químicos}

Os riscos químicos, de acordo com a definição dada pela Portaria 25, são as substâncias, compostos ou produtos que possam penetrar no organismo pela via respiratória, nas formas de poeiras, fumos, névoas, neblinas, gases ou vapores, ou que, pela natureza de atividade de exposição, possam ter contato ou ser absorvidos pelo organismo através da pele ou por ingestão.

É oportuna a lembrança de que, muitas substâncias que estão facilmente disponíveis nas residências e nas organizações nas quais se trabalha, são produtos originados na síntese química e como tal devem merecer especial cuidado, seja no lar, seja no trabalho. As recomendações e as informações constantes nos rótulos, quanto à sua guarda, conservação, deslocamento, manipulação ou destinação final de embalagens, entre outras formas de cuidado quanto ao trato devem estar disponíveis e ser lidas cuidadosamente, pois são adequadas e necessárias aos propósitos de prevenção e de socorro para acidentes envolvendo químicos.

Segundo Samuel Schvartsman (1988), em seu livro Produtos Químicos de Uso Domiciliar, descreve os possíveis danos à saúde causados por 
produtos de limpeza. Como exemplo, tem-se a água sanitária que pode causar irritação ou corrosão da pele e mucosas, lacrimejamento, edema de pálpebra, entre outros; os detergentes podem causar dermatite devido a ação irritante e desengordurante da pele; os desinfetantes podem causar irritação da mucosa ocular e outras mucosas, disfagia, vômitos e gastrite hemorrágica se ingeridos, distúrbios respiratórios, entre outros.

Em uma UAN os funcionários estão em contato com os produtos químicos durante as operações de limpeza e desinfeção do ambiente, seja de piso, paredes, pias e bancadas. Ocorre durante esse processo liberação de vapores de produtos químicos como sabão em pó, detergentes, desinfetantes, etc.. Existe ainda, o risco do contato epidérmico com esses produtos.

As medidas de controle que devem ser observadas, quanto à contaminação química, dentro de uma UAN são: respeitar as recomendações presentes nos rótulos dos produtos, principalmente quanto a sua diluição; utilização dos EPI (Equipamento de Proteção Individual) adequados (botas e luvas de borracha) durante a atividades de limpeza e desinfeção; sempre que possível, manter as janelas e portas abertas, ao realizar as operações de limpeza e desinfeção do ambiente para facilitar a dispersão dos vapores de produtos químicos.

\subsubsection{2 - Riscos Biológicos}

Os riscos biológicos relacionam-se à capacidade de organismos vivos, como bactérias, fungos, helmintos, protozoários e vírus, entre outros patogênicos, causarem doenças no organismo humano.

As principais vias de penetração são cutânea, respiratória, digestiva e parenteral.

Os principais agentes biológicos são: animais mortos, vísceras, insetos, água estagnada, lixo urbano, pacientes portadores de doenças infectocontagiosas, exsudatos animais, exsudatos humanos, materiais contaminados. 
O controle das fontes de transmissão deve-se basear, inicialmente, nas condições higiênicas dos ambientes de trabalho e sanitários e, acima de tudo, a conscientização, o treinamento e a formação de bons hábitos são imprescindíveis para evitar a contaminação.

Os funcionários de uma UAN estão em contato com bactérias, fungos, protozoários, vírus e demais organismos provenientes de resíduos de alimentos. Silva Jr. (2001) em seu Manual de Controle e Higiênico-Sanitário em Alimentos, fala sobre a contaminação do alimento via homem, mas pode ocorrer também a contaminação do homem, ao manipular os alimentos "in natura", principalmente carnes, que possuem uma carga microbiológica alta. Existe também o risco de contaminação ao manipular o lixo orgânico proveniente da fabricação do alimento.

As medidas de controle que devem ser observadas em uma UAN são: limpeza constante dos ambientes de trabalho de forma a impedir a formação de colônias de bactérias e fungos; armazenamento adequado dos gêneros alimentícios; lavagem das mãos antes e depois do contato com alimentos; adequada disposição final dos restos de alimentos, de forma que esses resíduos permaneçam o menor tempo possível no ambiente de trabalho; utilização de EPI (luvas e botas de borracha) para a manipulação do lixo.

\subsubsection{3 - Riscos Físicos}

Os riscos físicos são as diversas formas de energia a que possam estar expostos os trabalhadores, tais como ruído, vibrações, pressões anormais, temperaturas extremas, radiações ionizantes, bem como o infra-som e ultrasom.

\subsubsection{1 - Ruído}

Quando o som assume caráter indesejável, como sensações incômodas e até dolorosas, geralmente é chamado de ruído.

"O ruído afeta o homem simultaneamente nos planos físico, psicológico e social. Diversos estudos estão sendo conduzidos para determinar 
adequadamente a ação do ruído sobre outros sistemas além do auditivo. A literatura especializada registra alterações gastrointestinais (hipermotilidade e hipersecreção gastroduodenal), na visão (dilatação da pupila), cardiocirculatórias (vasoconstrição e hipertensão arterial), neuropsíquicas (ansiedade, irritação) e alterações na habilidade (redução do rendimento, aumento do número de erros e da possibilidade de acidentes). A isso tudo se acrescenta as constantes dificuldades introduzidas na comunicação entre pessoas provocadas por ruídos oriundos das mais diversas fontes." (Okamato e col., 1994)

Segundo a Fundacentro (1994), pode-se considerar a poluição sonora uma das formas de maior potencial danoso à saúde. Não é incomum a queixa de pessoas com redução na capacidade auditiva (hipoacusia).

As medidas de controle do ruído são basicamente de três ordens: na fonte, no meio e no homem. Prioritariamente, quando tecnicamente viável, a intervenção deve se dar na fonte, em seguida no meio e, em última instância, no homem.

O controle na fonte pode ser buscado com a execução de medidas técnicas na maquinaria e de medidas administrativas na produção. A redução da concentração de máquinas, a instalação de sistemas amortecedores, a reprogramação e redistribuição das operações, a substituição de peças de materiais rígidos por absorventes e a manutenção adequada estão entre as providências que devem ser tomadas no sentido de minimizar a emissão de ruído na fonte.

Para o controle do meio, deve-se evitar a propagação por meio de isolamento, da fonte e do receptor, e maximizar as perdas energéticas por absorção. $\mathrm{O}$ enclausuramento da fonte, o uso de barreiras, a adequação das características do ambiente e dos materiais utilizados na construção, permitindo o isolamento acústico deste, estão entre as medidas que podem ser tomadas com relação à intervenção no meio. 
Em último lugar, dentre as prioridades de controle, está o controle no homem ou no receptor. As medidas resumem-se à redução do tempo de exposição e à proteção sobre o indivíduo.

No anexo 1 da Normas Regulamentadoras No 15 (NR-15), encontra-se uma tabela que apresenta os limites de tolerância para o ruído contínuo ou intermitente. Ou seja, para aqueles que não se caracterizam como impacto. A sua leitura indica a permanência máxima que poderá ser efetuada por um indivíduo, sem proteção de modo que não haja dano à saúde do trabalhador durante sua vida laboral. ( Anexo C)

Segundo o livro Normas Regulamentadoras Comentadas da NR-15, o ruído contínuo ou intermitente apresenta três tipos de possíveis danos. O primeiro é a mudança temporária do limiar de audição (surdez temporária) que ocorre após a exposição do indivíduo a ruído intenso, mesmo por um curto período de tempo. Geralmente, essa perda é reversível. Pode ocorrer também a surdez permanente que se origina da exposição repetida, durante longos períodos, a ruídos de intensidade excessiva ocasionado por uma perda irreversível associada à destruição dos elementos sensoriais da audição. E trauma acústico que é a perda repentina, após a exposição a um ruído intenso, causado por explosões ou impactos sonoros. Conforme o tipo de lesão, pode haver somente uma perda temporária, mas que também pode ser permanente.

Em uma UAN, a produção de ruído é constante devido às máquinas, à água, ao vapor, ao choque de utensílios e ressonância de superfícies metálicas, ao sistema de exaustão e, também, devido ao diálogo entre os operadores. (Sousa, 1997)

Sousa e col.(1997), avaliaram as condições ergonômicas de sete UANs de Florianópolis, nas quais foram encontrados ruídos elevados em $100 \%$ dos setores de pré-preparo e 85,7\% dos setores de cocção.

Para uma jornada de trabalho de 8 horas, os níveis sonoros recomendados pela NR-15 são de 85 decibéis (dB), mas Kapnakis (1986) sugere um nível sonoro de $50 \mathrm{~dB}$ em restaurantes para garantir o bom desempenho dos operadores. 
Existe dificuldade em manter os níveis de ruídos adequados em UANs, em virtude da natureza das operações e equipamentos necessários. Recomenda-se análise quantitativa do ruído em cada local de trabalho dentro de uma UAN, para se determinar os níveis de pressão sonora em que estão sujeitos os funcionários da unidade.

\subsection{Temperatura}

O corpo humano realiza trocas de calor ao executar suas atividades metabólicas, em face da necessidade de regulação da temperatura do organismo, surgindo necessidade de reposições energéticas, de água e sais minerais. Estas, se não forem adequadamente supridas, podem trazer-lhes graves prejuízos à saúde.

Além da temperatura, deve-se também considerar a umidade e a ventilação ou a circulação local, cada qual com suas particularidades e exigências que, em conjunto, definirão uma condição termicamente confortável. Nesse sentido, terão influência, entre outros fatores, as vestimentas, a posição e a localização geográfica, bem como suas características construtivas (materiais, dimensões, coberturas, etc.). Há ainda a influência das exigências físicas impostas pela atividade realizada.

"O homem é um animal homeotérmico. Necessita, para sua sobrevivência, manter a temperatura interna de seu organismo constante. Essa temperatura é da ordem de $37^{\circ} \mathrm{C}$, com variações admissíveis entre $36,1 \mathrm{e}$ $37,2^{\circ} \mathrm{C}$, sendo os valores de $32^{\circ} \mathrm{C}$ e $42^{\circ} \mathrm{C}$ os limites extremos para a sobrevivência, em estado de enfermidade."(Barbosa Filho, 2001)

No trabalho físico intenso devem ser observadas variáveis como: vestimentas, características do ambiente que proporcionam trocas de calor entre o corpo e o ambiente, sexo, idade, biotipo, hábitos alimentares e demais variáveis determinantes nas trocas de calor e reposição energética.

O calor pode ocasionar prostração térmica, cujos sintomas são dor de cabeça, tonturas, mal estar e fraqueza, cãibras de calor ocasionadas pela 
perda excessiva de sais pelos músculos, devido a sudorese intensa, desidratação entre outros.

O frio pode causar doenças das vias respiratórias, rachaduras e/ou necrose da pele, problemas cardiovasculares, gangrena e erupção na pele.

"O ambiente de trabalho nas UANs costuma ser, na grande maioria das vezes, bastante quente e úmido, pelo desprendimento de calor e vapores no processo produtivo de elaboração de refeições, bem como os equipamentos de higienização de materiais."(Kanapis, 1986)

Segundo a Associação Brasileira de Refeições Coletivas (ABERC) (1998), o conforto térmico em uma UAN pode ser assegurado por abertura de paredes que permitam a circulação natural do ar, com área equivalente a 1/10 da área do piso. Caso isso não seja possível o ideal é recorrer a meios artificiais como exaustores. A temperatura compatível ao desenvolvimento do trabalho em UANs é de $22^{\circ}$ a $26^{\circ} \mathrm{C}$, com umidade relativa de 50 a $60 \%$.

O ambiente térmico em uma UAN merece atenção especial, devido à presença de grande número de equipamentos geradores de calor e umidade (fogões, fornos, fritadeiras, caldeirões a vapor, máquina de lavar pratos), os quais funcionando ao mesmo tempo em ambientes interligados dificultam a manutenção de uma temperatura agradável. (Santana, 1996)

Em uma UAN além dos trabalhadores estarem sujeitos ao calor proveniente dos equipamentos existentes, estão também sujeito ao frio proveniente da câmara de resfriamento, câmara frigorífico e freezeres localizados na área de produção.

Para minimizar os efeitos da temperatura para os funcionários de uma UAN algumas medidas de controle devem ser adotadas, como: manter o exaustor ligado durante o funcionamento do fogão industrial; manter as portas dos fundos e as janelas sempre abertas, garantindo assim ventilação natural; manutenção constante do sistema de desligamento automático ao abrir a câmara frigorífica; utilização de EPI como luvas térmicas para a retirada de alimentos dos fornos e do fogão, casaco térmico ao entrar na câmara frigorífica. Além dessas medidas deve ser adotado ciclos de trabalho para 
funcionários expostos diretamente ao calor, onde alterem funções realizando outras atividades sem contato direto com a temperatura elevada.

\subsubsection{3 - Riscos Mecânicos}

Os riscos mecânicos são os que se originam das atividades que envolvem máquinas e equipamentos, responsáveis pelo surgimento das lesões nos trabalhadores quando da ocorrência dos acidentes de trabalho. Tem-se os exemplos mais comuns de agentes mecânicos: máquinas e equipamentos sem proteção, ferramentas defeituosas, ferramentas inadequadas, etc.

Qualquer risco gerado por agentes ambientais é risco de acidente, donde se entende, também, as doenças do trabalho.

Os acidentes envolvendo riscos mecânicos mais comuns em uma UAN são cortes nos membros superiores devido à manipulação de facas e acidentes envolvendo improvisos e/ou adaptações devido a equipamentos defeituosos ou estragados.

Dentro das medidas preventivas para riscos mecânicos, deve ser elaborado programa de manutenção de equipamentos e uso de EPI adequados como luva de malha de aço para pré-preparo de carnes.

\subsubsection{Medição dos Riscos Ambientais}

As medições dos riscos ambientais se dão através do Programa de Prevenção de Riscos Ambientais (PPRA) e Programa de Controle Médico de Saúde Ocupacional (PCMSO).

\subsubsection{Programa de Prevenção dos Riscos Ambientais - PPRA}

A obrigatoriedade do PPRA, pela nova redação dada à NR-09, atinge todas os estabelecimentos das empresas que possuam empregados, independente do tamanho e grau de risco, desde que regidos pela CLT.

O objetivo do PPRA é a preservação da saúde e da integridade dos trabalhadores, através da antecipação, avaliação e controle de riscos 
ambientais existentes no local de trabalho, levando em consideração a proteção do meio ambiente e dos recursos naturais.

O PPRA faz parte de um conjunto de medidas mais amplas, contidas nas demais normas regulamentadoras, porém principalmente, com a NR-07, ou seja, com o PCMSO. Suas ações são tomadas através da antecipação, reconhecimento, avaliação e consequente controle da ocorrência de riscos ambientais existentes ou que venham a existir no ambiente de trabalho.

A formulação do PPRA é atribuição dos Engenheiros de Segurança do Trabalho e dos Técnicos de Segurança do Trabalho.

\subsubsection{Programa de Controle Médico de Saúde Ocupacional - PCMSO}

O Ministério do Trabalho, através da Secretaria de Segurança e Saúde no Trabalho (SSST), entende que "todos os trabalhadores devem ter o controle de sua saúde de acordo com os riscos a que estão expostos. Além de ser uma exigência legal prevista no artigo 168 da CLT, está respaldada na Convenção 161 da Organização Internacional do Trabalho (OIT), respeitando princípios éticos, morais e técnicos".

A responsabilidade pela implementação desse programa é única e total do empregador, devendo ainda zelar pela sua eficácia e custear despesas, além de indicar Médico do Trabalho para coordenar a execução do programa.

Segundo a SSST, as empresas desobrigadas de possuir médico coordenador deverão realizar os exames, através de médico, que para a realização dos mesmos, deverá necessariamente conhecer o local de trabalho. Sem a análise do local de trabalho, será impossível uma avaliação adequada da saúde do trabalhador.

Cabe ao médico do trabalho realizar os exames médicos, ou encarregálos a profissional médico familiarizado com os princípios da patologia ocupacional e suas causas, bem como com o ambiente, as condições de trabalho e os riscos a que está ou será exposto cada trabalhador da empresa a ser examinado. 
Para que seja atendido esse critério é necessário que o médico tenha acesso a Análise de Riscos por Função ou Atividade, que é uma das etapas do PPRA, fundamental para início dos trabalhos do PCMSO.

O mínimo que requer o programa é um estudo "in loco" para reconhecimento prévio dos riscos ocupacionais existentes. O reconhecimento de riscos deve ser feito através de visitas aos locais de trabalho para análise dos processos produtivos, postos de trabalho, informações sobre ocorrências de acidentes de trabalho e doenças ocupacionais, entre outros.

\section{3- EQUIPAMENTO DE PROTEÇÃO COLETIVA - EPC}

"Os equipamentos de proteção coletiva são dispositivos utilizados no ambiente laboral com o objetivo de proteger os trabalhadores dos riscos inerentes aos processos."(Piza, 1997)

Normalmente os EPC envolvem facilidades para os processos industriais colaborando no aumento de produtividade e minimizando os efeitos de perdas em função de melhorias nos ambientes de trabalho.

Os EPC podem ser equipamentos simples, como corrimãos de escadas até sistemas sofisticados de detecção de gases dentro de uma planta química.

Uma das maiores vantagens que o EPC possui frente a outros sistemas de proteção é que além de proteger a coletividade, não provoca desconforto aos trabalhadores, pois os EPC são instalados no ambiente e não nas pessoas.

Os equipamentos de proteção coletiva não prejudicam a eficiência do trabalho, quando adequadamente escolhidos e instalados. Os EPCs devem ser do tipo adequado em relação ao risco que irão neutralizar; depender o mínimo possível da atuação do homem para atender suas finalidades; ser resistente à agressividade de impactos, corrosão, desgastes a que estiverem sujeitos; permitir facilidade de limpeza, lubrificação e manutenção; não criar outros tipos de riscos, principalmente mecânicos como obstrução de passagens e formação de cantos vivos. 


\section{4 - EQUIPAMENTO DE PROTEÇÃO INDIVIDUAL - EPI}

Equipamento de proteção individual é todo dispositivo de uso individual destinado a proteger a saúde e a integridade física do trabalhador.

De acordo com o que estabelece o artigo 166, da Seção IV, do capítulo V, Título II da CLT (LEI 6.514/77) o EPI deverá ser adotado "... sempre que as medidas de ordem geral não ofereçam completa proteção contra os riscos de acidentes e danos à saúde dos empregados".

Do ponto de vista prevencionista o EPI não evita acidentes. Ele existe para evitar a lesão ou atenuar sua gravidade, além de proteger o corpo e o organismo contra efeitos de substâncias químicas que possam determinar doenças ocupacionais.

Antes da empresa optar pela adoção do EPI deverá adotar medidas de proteção coletiva que possam eliminar ou neutralizar as ações dos riscos ou agentes ambientais presentes nos locais de trabalho.

O EPI, além de proteger o trabalhador contra agentes ambientais inerentes ao processo, deve ser na medida do possível confortável.

Ao empregado compete utilizar o EPI apenas para a finalidade a que se destina responsabilizando-se por sua guarda e conservação, devendo comunicar ao empregador qualquer alteração que o torne impróprio ao uso.

Não se deve estabelecer tempo mínimo de vida para um EPI, vinculando sua substituição a esse prazo tendo em vista que o objetivo dele é proteger o trabalhador em caso de acidentes.

É obrigação das organizações fornecer material de proteção de boa qualidade e confiabilidade. Por isso, deverão exercer um rigoroso controle sobre as origens, a guarda e conservação de seus equipamentos de proteção.

Recomenda-se que ao adiquirir um EPI o empregador exija do fabricante cópia do Certificado de Aprovação (CA) e, também, cópia do Certificado de Registro do Fabricante (CRF) ou Certificado de Registro do Importador (CRI). 
A eliminação ou neutralização da insalubridade, segundo estabelece o artigo 191, da Seção XIII, do Capítulo V, Título II da CLT ocorrerá, se "com a utilização de equipamentos de proteção individual pelo trabalhador, que diminua a intensidade de agente agressivo a limites de tolerância".

Dentre os equipamentos de proteção individual que os funcionários de uma UAN devem utilizar estão luvas de borracha, bota de borracha, luvas térmicas, casaco térmico, luva de malha de aço e outros.

\subsection{DISTÚRBIOS OSTEOMUSCULARES RELACIONADAS AO TRABALHO - DORT}

\subsubsection{Conceito a Aplicação}

As afecções músculo-esqueléticas relacionadas com o trabalho, que no Brasil tornaram-se conhecidas como Lesões por Esforços Repetitivos (LER), hoje denominadas de Doenças Osteomusculares Relacionadas ao Trabalho (DORT), representam o principal grupo de agravos à saúde, entre as doenças ocupacionais no Brasil.

A siglas LER e DORT foram criadas para identificar um conjunto de doenças do trabalho que atingem os músculos, tendões e nervos e que têm relação direta com as exigências das tarefas dos ambientes físicos e da organização do trabalho. São inflamações provocadas por atividades de trabalho que exigem do funcionário movimentos manuais repetitivos, contínuos, rápidos e vigorosos durante um período de tempo.

As lesões trazem como conseqüência a perda da capacidade de realizar movimentos. Essa perda da capacidade pode ser parcial e, caso o trabalhador não seja afastado da atividade repetitiva, essa perda poderá ser total.

Os músculos são responsáveis por todos os movimentos do corpo. São eles que transformam a energia química armazenada no corpo em contrações, que são os movimentos. 
"Quando um músculo contrai-se estrangula as paredes dos capilares diminuindo, ou impedindo, a circulação sangüínea causando fadiga muscular. Assim, para facilitar a circulação do sangue o músculo deve contrair-se e relaxar com uma intensidade de freqüência em determinado tempo. Quando essa freqüência e tempo não são respeitados a ponto de impedir a reprodução celular e restabelecer o equilíbrio energético do músculo, ocorre a lesão muscular."(Piza, 1997)

As LER/DORT são um grupo heterogêneo de distúrbios funcionais e/ou orgânicos que apresentam indução por fadiga muscular causado por trabalho realizado em posição fixa (trabalho estático) ou com movimentos repetitivos; falta de tempo de recuperação pós-contração muscular, devido a falta de flexibilidade de tempo e ritmo acelerado de trabalho.

O quadro clínico das LER/DORT é variado onde aparecem queixas de dor, formigamento, dormência, choque, peso e fadiga precoce.

"Os fatores de risco que mais predispõe o trabalhador a LER/DORT são trabalho automatizado, onde o trabalhador não tem controle sobre suas atividades; obrigatoriedade de manter ritmo acelerado de trabalho para garantir a produção; trabalho fragmentado, onde cada um exerce uma única tarefa de forma repetitiva; número inadequado de funcionários; jornadas inadequadas de trabalho, com frequente realização de horas extras; ausência de pausas durante jornada de trabalho; trabalho realizado em ambientes frios, ruidosos e mal ventilado; mobiliário inadequado, que obriga a adoção de posturas incorretas do corpo durante a jornada de trabalho."(Piza, 1997)

"A clareza sobre a gênese das LER/DORT é fundamental para que sejam propostas medidas eficazes para o diagnóstico, tratamento, reabilitação e prevenção desses distúrbios. Estudos demonstram que muitas tentativas de intervenção em ambientes de trabalho "patogênicos" visando a prevenção desse conjunto de doenças não surtem efeito, pois não levam em consideração a organização do trabalho, os fatores 
biomecânicos e ambientais como determinantes primordiais do adoecimento."(Ministério da Saúde, 2001)

Uma análise ergonômica mostrará os pontos críticos do trabalho, por meio do estudo da atividade real dos trabalhadores. A partir daí, identificará os riscos e suas características moduladores para detectar o desequilíbrio encontrado entre o posto de trabalho e o homem, passível de propiciar um aumento da carga de trabalho e ocasionar conseqüências negativas para a saúde. No caso das LER/DORT, dada a multiplicidade de fatores que predispõem ao seu aparecimento, esta análise tem por finalidade identificá-los para a instalação de um programa de prevenção.

A presença de um fator de risco no trabalho não é suficiente para desencadear LER/DORT; para o seu aparecimento seria necessário um determinado grau de gravidade (importância) e conjunção de outros fatores.

O fator de risco apresenta três características moduladoras: intensidade, freqüência e duração. Quanto mais intenso, frequente e duradouro, tanto mais elevado é o risco.

Vários fatores de risco associados às LER/DORT podem não causar diretamente o problema, mas favorecem as reações fisiopatológicas que determinam seu aparecimento.

"A repetitividade é o fator de risco mais freqüentemente referido, mas não é o único fator biomecânico determinante, pois LER/DORT podem aparecer também não ligadas à repetitividade, mas a cargas e posturas estáticas".(Ministério da Saúde, 2001)

A repetitividade interage com outros fatores e têm seus efeitos potencializados. Para o estudo do fator repetitividade e suas possíveis repercussões na saúde, deve-se caracterizar a duração dos ciclos de trabalho, seu conteúdo e o custo humano no trabalho. 
A invariabilidade do trabalho, refere-se à atividade que é sempre a mesma durante toda a jornada de trabalho. É um conceito ligado à repetitividade. As tarefas monótonas, com posturas imobilizadas pelas exigências do trabalho, parecem apresentar risco maior para a ocorrência de LER/DORT.

Posturas inadequadas, são posturas assumidas pelos trabalhadores para realizarem as operações do ciclo de trabalho, geralmente, quando de trabalho é inadaptado. Uma postura é inadequada quando, por exemplo, o corpo tem de lutar contra a gravidade para mantêlo. Para cada articulação, pode-se definir uma postura de base em que as exigências ligadas à sua manutenção são mínimas e as estruturas anatômicas estão em posições favoráveis.

As posturas no trabalho vão depender do estado físico do homem, da disposição das máquinas e dos equipamentos no espaço de trabalho, das características do ambiente, da forma das ferramentas e suas condições de utilização, do produto utilizado, do conteúdo das tarefas, da cadência e ritmo de trabalho e da freqüência das pausas.

Os fatores que favorecem a ocorrência das LER/DORT são múltiplos. Constituem um conjunto complexo; isolados ou agrupados, mas interligados, exercem seus efeitos simultaneamente.

É preciso se ter claro que as dimensões de um posto de trabalho ou as demandas visuais decorrentes da exigência das tarefas não causam problemas músculo-esqueléticos, no entanto, esses fatores podem tornar obrigatória a adoção de posturas e métodos de trabalho que poderão provocar ou agravar as manifestações de LER/DORT.

Também não se pode esquecer que o esforço mental exigido por uma tarefa influi sobre o estresse psicológico e sobre o comportamento e que uma sobrecarga quantitativa ou sobrecarga qualitativa podem desencadear reações de estresse, logo, um risco para a ocorrência de LER/DORT. 
Análises de estudos epidemiológicos de avaliação quantitativa, que correlacionam os movimentos repetitivos com dor de membros superiores, indicam uma associação entre repetitividade do trabalho e afecções do punho e antebraço. Poucos estudos quantificam fatores como força, carga estática, postura, velocidade de movimentos e duração da exposição.

No entanto, o peso e o papel, isoladamente, de cada um dos fatores envolvidos continuam indefinidos. Assim, o que os estudos mostram é que na maioria dos casos a conjugação de vários fatores de risco favorecem a ocorrência de LER/DORT.

Um estudo ergonômico sério é um ponto de partida para a resolução dos problemas. Posteriormente, deve ocorrer acompanhamento da implantação das mudanças propostas, avaliação contínua dos resultados, de forma conjunta com os trabalhadores, e ajuste das medidas necessárias.

\subsubsection{Tratamento e Reabilitação}

"Atualmente, no Brasil, as experiências dos serviços de referência em saúde do trabalhador mostram que raramente faz-se diagnóstico precoce de LER/DORT; a maioria dos pacientes que procura o ambulatório médico já enfrenta o problema há muito tempo". (Ministério da Saúde, 2001)

Existe um subdiagnóstico de LER/DORT, os pacientes procuram o serviço de saúde apenas após muito tempo do aparecimento de sintomas, ou porque não os percebem, ou porque negam a possibilidade de estarem com problemas ou por medo da marginalização, discriminação e demissão. E muitas vezes, quando procuram o médico ao apresentarem alguns sintomas precoces, não recebem atenção devida do profissional, ou por sua falta de preparo ou por pressão da empresa sobre ele.

"No caso de LER/DORT, sabe-se que mesmo quando diagnosticados, nem sempre são notificados à seguradora, em especial à Previdência Social, ou porque há resistência por parte da empresa ou porque o próprio paciente não o deseja, para não ser estigmatizado entre os colegas e no mercado de trabalho".(Ministério da Saúde, 2001) 
Há uma fase inicial na qual os sintomas são fruto basicamente de um processo de fadiga incipiente ou inflamação. É uma fase na qual o paciente sente desconforto e não necessariamente dor, e passa despercebida na maioria dos casos. Nessa fase pode-se obter um completo restabelecimento orgânico e funcional, caso haja orientação ao paciente e afastamento das causas. Porém, a manutenção das atividades laborais executadas da mesma maneira em geral agrava o quadro clínico.

Nas fases mais avançadas, nas quais estão envolvidos mecanismos neurogênicos e de hiperalgesia secundária, e nos quais já há uma alteração do sistema modulador da dor, o que se pode obter é o controle e o equilíbrio dos sintomas, mas dificilmente a sua regressão total.

A dor pode ou não gerar incapacidade laboral. A capacidade ou incapacidade laborais dependerão da existência ou não de uma política de prevenção e reabilitação na empresa, do estado físico e psicológico do paciente.

A reabilitação deve começar no mesmo momento do tratamento, mas não se encerra com o término deste e com o início da realocação do trabalhador na empresa: é necessário acompanhar o processo de volta ao trabalho de forma que o paciente possa trabalhar novamente sem riscos de adquirir ou acentuar lesões.

No caso de LER/DORT não há um tempo determinado de exposição e as condições de trabalho e os fatores organizacionais variam. $\mathrm{O}$ que se deve levar em conta é que as pessoas ficam períodos variados expostas não a um fator apenas, mas a muitos, com intensidades e freqüências variadas. Há casos em que pacientes ficaram expostos durante um mês e outros em que ficaram expostos por mais de dez anos, até adquirir o problema.

Os hábitos que possam causar ou agravar sintomas do sistema músculo-esquelético devem ser objeto de investigação: uso excessivo de computador em casa, lavagem manual de grande quantidade de roupas, ato de tricotar, dirigir, etc. 
Essas atividades acima citadas geralmente agravam o quadro de LER/DORT, mas dificilmente podem ser consideradas causas determinantes dos sintomas, uma vez que são atividades com características de flexibilidade de ritmo e tempos.

Não se deve confundir tarefas domésticas com atividades profissionais de limpeza, faxina ou cozinha industrial. Estas últimas são consideradas de risco para ocorrência de LER/DORT.

Em uma UAN várias atividades desenvolvidas por seus funcionários estão enquadradas como risco de LER/DORT como, descascar e picar grandes quantidades de hortaliças, porcionar carnes, refogar alimentos, carregar bandejas, entre outras. A maioria das funções em uma unidade de produção de alimentos são realizadas em pé e com movimentos repetitivos.(Casarotto e col., 1997)

O trabalho parado, em pé, exige o trabalho estático da musculatura envolvida para manutenção da posição referida provocando facilmente a fadiga muscular. Além disso, há um aumento importante da pressão hidrostática do sangue nas veias das pernas e o progressivo acúmulo de líquidos tissulares nas extremidades inferiores favorecendo uma maior incidência de varizes e edemas de tornozelo.(Gradjean, 1998)

As tarefas que exigem longo tempo em pé devem ser intercaladas com tarefas que possam ser executadas na posição sentada ou andando, a fim de evitar a fadiga nas costas e pernas e, também, prevenir varizes.

\subsubsection{Prevenção}

A abordagem global preventiva deve avaliar todos os elementos do sistema de trabalho: o indivíduo, os aspectos técnicos do trabalho, ambiente físico e social, a organização do trabalho e as características da tarefa.

No centro deste sistema está o ser humano influenciado pelos elementos da atividade laboral, isto é, o conjunto de ações e gestos que definem a tarefa a executar. 
Ao conhecer os mecanismos fisiológicos e psicológicos do ser humano, pode-se entender que distúrbios de saúde podem surgir quando limites são ultrapassados, como ocorre no caso de trabalhos repetitivos e/ou posturas estáticas prolongadas.

Para compreender essa problemática, deve-se analisar algumas questões básicas, como por exemplo:

Como são as máquinas e ferramentas?

O mobiliário e o ambiente físico são adequados?

Quais as posturas estáticas?

Quantas horas de trabalho?

Há pressão para se produzir e quanto?

\subsubsection{Metas de Prevenção}

"A meta da boa prevenção deve utilizar estratégias que melhorem a higidez nos postos de trabalho, programas de formação e medidas de amparo aos trabalhadores acometidos".(Ministério da Saúde, 2001)

É necessário interferir desde os primeiros estágios de desenvolvimento do quadro clínico, não se esperar a instalação e desenvolvimento de incapacidades permanentes. Tenha-se sempre em mente que um dos indicadores da existência de problemas em postos de trabalho são as queixas de dor sentidas pelos trabalhadores.

A prevenção primária de LER/DORT deve reduzir os fatores de risco laborais ao se melhorar as condições gerais de trabalho. É recomendado utilizar-se a análise do trabalho.

A ergonomia sistemática e rigorosamente utilizada, permite transformar as situações de trabalho, adaptando-se às possibilidades e capacidades do trabalhador.

A finalidade da intervenção ergonômica é transformar a situação de trabalho e permitir o melhor conhecimento sobre a atividade real do 
trabalhador. Detectando-se os pontos de desequilíbrio entre o homem e seu posto de trabalho, torna-se possível o perfeito questionamento das relações saúde/trabalho, principalmente, de suas conseqüências negativas (acidentes de trabalho, doenças profissionais e do trabalho, etc.), possibilitando também questionar as exigências da produção (quantidade e qualidade, etc.).

\subsubsection{Como Prevenir}

A prevenção de LER/DORT se faz através de programas de supervisão dos ambientes de trabalho visando conceber e gerar soluções em busca de melhorias, seguindo as seguintes etapas:

Na primeira etapa, analisando os prontuários médicos e buscando sinais e sintomas de LER/DORT, é bom lembrar: certamente o número de pessoas com queixas na empresa será maior do que o de pacientes com queixas no ambulatório. As listas de controle dos fatores de risco, significam importante ponto de partida.

Na segunda etapa, após detecção preliminar dos postos de trabalho com mais riscos ao trabalhador, levantam-se os sintomas característicos desse grupo de doenças em questionários e análises do trabalho, para se conhecer tudo referente às atividades realizadas nos postos de trabalho.

Por fim, abrir consulta médica detalhada aos trabalhadores atingidos pelo problema, para caracterizar os tipos de acometimento e sua relação com as condições de trabalho. Finalmente, intervenções ergonômicas, inicialmente, nos postos mais críticos, negociando-se melhorias a curto, médio e longo prazos. A avaliação posterior à implantação das melhorias é fundamental para eventualmente a solução proposta não se transformar em novo fator de risco ao trabalhador.

Participação e treinamento dos profissionais envolvidos na problemática saúde/trabalho, que passariam a compreender a teia de fatores predisponentes e desencadeantes das LER/DORT, e fariam, então, o diagnóstico da situação de trabalho para propor as melhorias necessárias. 
Os bons programas de prevenção devem compreender os postos de trabalho, visando à saúde de quem neles trabalham. No caso das LER/DORT, o estudo desses postos pode mostrar a necessidade de correções que, no primeiro momento parecerão inatingíveis por depender de muitos fatores organizacionais para se concretizar.

Para as propostas de melhoria poderem ser encaminhadas, é importante conhecer os itens a discutir em uma real prevenção, como:

\subsection{Alternância das tarefas e rotação nos postos de trabalho}

A alternância nos postos de trabalho objetiva a melhoria ergonômica das condições de trabalho. Os postos mais exigentes quanto a repetitividade ou manutenção de posturas estáticas, que não podem ser modificados a curto prazo, devem ser ocupados mediante rodízio; isto vai possibilitar diminuição na duração da exposição aos fatores de risco, aí presentes.

A diversificação visa igualmente diminuir a monotonia inerente ao trabalho repetitivo.

É necessário que as tarefas tenham conteúdo diversificado, com solicitação de vários grupos musculares.

\subsection{Pausas}

A recuperação muscular só é alcançada se houver descanso suficiente dessas estruturas anatômicas.

Não há uma "receita" pronta para se estabelecer as freqüências e a duração ideais das pausas necessárias para a recuperação orgânica do trabalho repetitivo ou em posturas estáticas, em qualquer ramo de atividade.

Pode-se afirmar que quanto menor o ciclo de trabalho, mais freqüentes e duradouros devem ser as pausas.

2.5.3.2.3 Redução na jornada de trabalho 
A redução da jornada de trabalho diminui a exposição aos fatores de risco. No caso de quem trabalha com digitação em processamento de dados no Brasil, ficou estabelecida uma jornada de trabalho efetiva de 5 horas.

Jornadas de trabalho muito longas, ou seja, superiores a 8 horas diárias acabam tornando-se improdutivas, pois quando submetidos a longas jornadas o operador tende a reduzir seu ritmo de trabalho a fim de acumular reservas para suportar as horas-extras. (Grandjean, 1998)

Segundo Grandjean (1998), inúmeras são as evidencias de que o trabalho extra não só prejudica a produção/hora, como ainda traz um aumento do absenteísmo, acompanhado de doenças e acidentes.

A UAN, por ser enquadrada no setor de prestação de serviços, tem seu horário de trabalho condicionado às necessidades de seu cliente. Sendo assim, a UAN de um hospital praticará horários compatíveis com o atendimento das necessidades dos pacientes, enquanto UANs localizadas em indústrias devem funcionar de acordo com os seus turnos produtivos.

\subsection{Revisão da produtividade e das formas de controle da supervisão}

Dependendo da possibilidade de expressão dos operadores sobre seus anseios e dificuldades no trabalho, haverá discussão para a procura de soluções nos postos de trabalho.

Outra característica importante do setor de alimentação coletiva é a pressão temporal da produção, que acaba impondo um ritmo de trabalho intenso. Esta pressão é decorrente de características peculiares do produto (alimento), como por exemplo sua perecibilidade e a necessidade de cuidados temporais na sua manipulação. Além disso, outro fator que torna o tempo de produção limitado e com pouca flexibilidade, é a necessidade de ajuste com horários de distribuição das refeições.

Dentro deste contexto, faz-se necessário o diálogo entre os operadores e a supervisão da UAN para elaboração de mapa de atividades, levando em 
consideração a rotatividade de tarefas e postos de trabalho e a demanda de trabalho a ser realizado.

\subsection{Treinamento}

O treinamento deve ter um papel complementar dentro do conjunto das medidas preventivas.

Quando discute-se sobre treinamento de trabalhadores para desempenho de determinada tarefa repetitiva, não se pensa em "bons métodos" ou "boas posturas" a serem utilizadas por eles.

As posturas adotadas pelos trabalhadores no desempenho de suas funções são condicionadas por vários fatores, como: seu estado físico e estatura, disposição do posto de trabalho, conteúdo da tarefa, exigência de tempo e freqüência e duração das pausas.

As informações técnico-organizacionais e as conseqüências positivas e negativas do trabalho são importantes, por fornecer ao homem os meios de compreender e estabelecer as estratégias em seu sistema laboral. A partir daí o ambiente de trabalho, deixando aberto ao trabalhador um canal de expressão, para que exponha sua dificuldade e atue melhor.

No caso dos operadores de postos de trabalho, o simples fato de poderem detectar os fatores de risco e os sintomas das LER/DORT precocemente é muito importante na prevenção dessas doenças.

Noções básicas de ergonomia devem ser ensinadas para que essa formação seja adequada no entendimento e na prevenção das LER/DORT.

\subsection{Acompanhamento dos trabalhadores acometidos}


Todo programa de prevenção deve incluir elementos para a prevenção secundária (diagnóstico precoce) e terciária (prevenção do agravamento), para que se contemplem os trabalhadores que apresentam sintomas de LER/DORT.

Deve estar claro para todo o responsável por serviços de saúde que, ao se deparar com um trabalhador acometido de LER/DORT, a busca das causas dessa doença deve se direcionar ao posto de trabalho, e não ao ser humano que aí desenvolve as suas atividades. As causas das LER/DORT se encontram nos trabalhos repetitivos e em posturas estáticas e não nas características individuais dos seres humanos.

Deve-se ter em conta que a prevenção não tem começo, meio e fim. É um processo contínuo, no qual constroi-se uma prática de diálogo entre administradores, trabalhadores e técnicos, que juntos podem promover mudanças que não só beneficiem a qualidade de vida no trabalho como tambem melhorem o desempenho da empresa.

"Os pacientes com LER/DORT enfrentam situações como medo de demissão, medo de ser isolado pelos colegas, amigos e familiares, dificuldade de encontrar tratamento adequado, presença constante de dor, limitação em suas atividades laborais e extra-laborais, necessidade de readaptações nem sempre possíveis, incerteza profissional e na vida."(Ministério da Saúde, 2001)

\subsection{ERGONOMIA}

\subsubsection{Conceito e Aplicação}

"Ergonomia é o conjunto de conhecimentos a respeito do desempenho do homem em atividade, a fim de aplicá-los à concepção das tarefas, dos instrumentos, das máquinas e dos sistemas de produção". (Laville, 1977)

Segundo a Ergonomics Research Society, Inglaterra: "Ergonomia é o estudo do relacionamento entre o homem e o seu trabalho, equipamento e ambiente, e particularmente da aplicação dos conhecimentos de anatomia, 
fisiologia e psicologia na solução dos problemas surgidos desse relacionamento".

Por definição dos radicais temos Ergon que significa trabalho e Nomos que significa leis. A palavra origina-se do latim e significa leis que regem o trabalho. Do ponto de vista técnico, com base no que determina a portaria $n^{\circ}$ 3.751, de 23 de novembro de 1990, que alterou a NR-17, entende-se por ergonomia o conjunto de parâmetros que devam ser estudados e implantados de forma a permitir a adaptação das condições de trabalho às características psicofisiológicas dos trabalhadores, de modo a proporcionar um máximo conforto, segurança e desempenho eficiente.

"Os objetivos práticos da ergonomia são a segurança, satisfação e bemestar dos trabalhadores no seu relacionamento com sistemas produtivos".(Lida, 1990)

Inúmeros fatores influenciam as relações entre o homem e sua tarefa, modificando a carga de trabalho. Alguns deles se constituirão no campo de ação da Ergonomia, como: as características materiais do trabalho, que levam em consideração o peso dos instrumentos, a resistência dos comandos, a dimensão dos postos de trabalho; o meio ambiente físico (ruído, iluminação, vibrações, ambiente térmico); a duração, os horários e as pausas de trabalho; e o modelo de aprendizagem, as ordens dadas.

A ergonomia visa contribuir para a concepção ou a transformação das situações de trabalho, tanto relação aos seus aspectos técnicos como os sócioorganizacionais, a fim de que o trabalho possa ser realizado respeitando a saúde e a segurança dos homens e com o máximo conforto e eficácia.

A ergonomia atualmente é distinta entre ergonomia de correção e de concepção. A ergonomia de correção procura melhorar as condições de trabalho existentes e, frequentemente, é parcial e de eficácia limitada. A ergonomia de concepção tende a introduzir os conhecimentos sobre o homem desde a fase inicial do projeto, do instrumento, da máquina ou dos sistemas de produção.

"Os benefícios da ergonomia são representados pelos bens e serviços produzidos. No caso de uma mudança de proposta de produção, devem ser estimados os aumentos de produtividade e de qualidade, a redução dos desperdícios, as economias de energia, mão de obra, manutenção, e assim por diante. Existem outros benefícios de mais difícil mensuração, como redução das faltas de trabalhadores devido a acidentes e doenças ocupacionais. 
Finalmente, existem os benefícios chamados de intangíveis, que não podem ser calculados objetivamente, mas apenas estimados, nem por isso menos importantes, como a satisfação do trabalhador, o conforto, a redução da rotatividade e o aumento da motivação e do moral dos trabalhadores."(Lida, 1990)

A metodologia ergonômica baseia-se em dois pontos principais: observar a atividade do trabalho e entrevistar os trabalhadores.

A observação sistemática objetiva avaliar-se os elementos pertinentes à carga de trabalho real do operador, em relação às diferentes exigências da situação de trabalho, e a entrevista revela a visão do trabalhador sobre seu trabalho.

A finalidade da intervenção ergonômica é transformar a situação de trabalho e permitir o melhor conhecimento sobre a atividade real do trabalhador. Detectando-se os pontos de desequilíbrio entre o homem e seu posto de trabalho, torna-se possível o perfeito questionamento das relações saúde/trabalho, principalmente, de suas conseqüências negativas, como acidente de trabalho, doenças profissionais e do trabalho, fadiga industrial, psicopatologia do trabalho, possibilitando também questionar as exigências da produção quanto à quantidade e qualidade.

\subsubsection{Análise ergonômica do trabalho}

Os processos de transformação da atividade profissional e 0 desenvolvimento dos conhecimentos ergonômicos são baseados em, uma intervenção no local de trabalho, denominada Análise Ergonômica do Trabalho $(A E T)$.

A AET possibilita não somente categorizar as atividades dos trabalhadores, como também estabelecer a narração dessas atividades permitindo, consequentemente, modificar o trabalho ao modificar a tarefa.

As etapas deste método envolvem análise da demanda, análise da tarefa e análise da atividade que subsidiarão um diagnóstico e recomendações para a melhoria da situação em questão. 
A demanda é o ponto de partida de toda a análise ergonômica do trabalho. Caracterizando-se pelo momento da definição do problema a ser analisado, descrevendo os postos de trabalho, procurando evidenciar os aspectos ergonômicos mais importantes, a fim de caracterizar a problemática.

A tarefa pode ser definida convencionalmente como sendo aquilo que se apresenta ao trabalhador, ou seja, a máquina, o meio físico que rodeia o posto de trabalho, as instruções às quais se prevê que o operador obedeça, os objetivos a serem alcançados, bem como o controle e as sanções aplicadas.

Existe diferença entre o trabalho real, a atividade, do trabalho prescrito, sendo que o último constitui a tarefa prevista pelas normas, enquanto que o trabalho real é aquele que se desenrola efetivamente no local de trabalho.

A atividade consiste na apresentação do comportamento do homem na situação real de trabalho. No levantamento dos comportamentos do homem no trabalho, são considerados comportamentos que possam ser analisados através de métodos e técnicas que sejam aplicáveis a determinada situação de trabalho.

O diagnóstico de uma situação de trabalho é um produto essencial de uma análise ergonômica. Esta é orientada pelos elementos identificados na análise da demanda, no funcionamento da empresa, na síntese dos resultados das observações e medidas, e nas explicações fornecidas pelos empregados. Permitindo assim, a transformação da situação de trabalho.

Após o diagnóstico da situação de trabalho na UAN, as áreas ou setores que a compõem devem ser planejadas seguindo uma linha racional de produção, obedecendo a um fluxo coerente, de modo a evitar cruzamentos indesejáveis, retrocessos e até mesmo acidentes de trabalho, que comprometem a produção das refeições ou a saúde dos trabalhadores. (Manual da ABERC, 1998)

Segundo Teixeira e col. (1990), a área física de uma UAN necessita de instalações adequadas aos objetivos propostos. Um planejamento físico adequado permite inclusive melhor utilização dos recursos humanos, através 
do dimensionamento do contigente de mão-de-obra necessário e definição das tarefas a serem executadas, de que resulta maior racionalização de trabalho e, consequentemente, menor fadiga .

No planejamento da área física de uma UAN, devem ser considerados fatores como: localização, fluxo de trabalho, fluxo de produtos, espaço de trabalho, acesso às áreas subordinadas, áreas de preparação de alimentos, equipamentos disponíveis, tipo de cardápio, número de refeições.(Kinton e col., 1999)

Além disso, através de um planejamento adequado é possível evitar movimentos desnecessários por parte dos operadores, minimizando a sua fadiga e, concomitantemente, otimizando a produção.

Para traçar o perfil ergonômico de uma UAN deve-se levar em consideração a postura e os movimentos exercidos pelos funcionários. Postura, segundo Haslegrave (1994), surge da demanda funcional da visão, alcance, manipulação, força e tolerância, estabelecida com a relação geométrica entre a antropometria do operador e o leiaute do posto de trabalho. Já os movimentos são exigências de várias tarefas que levam a um gasto de energia podendo provocar sobrecarga nos músculos, coração e pulmões (Dul e col., 1993).

É necessário considerar que pode surgir um estresse adicional quando o operador mantém posição onde a cabeça e o tronco ficam inclinados ao realizar uma tarefa, provocando dores no pescoço e nas costas. Por isso, é importante projetar postos de trabalho que permitam alterar a postura sentada com a postura em pé, mantendo espaço mínimo para as pernas. (Dul e col., 1995)

"Para a configuração dos locais de trabalho, a escolha da correta altura de trabalho é de essencial importância. Assim, se a área de trabalho é muito alta, frequentemente os ombros são erguidos para compensar, o que leva a contrações musculares dolorosas, principalmente na nuca e nas costas. Por outro lado, se a área é baixa, as costas são sobrecarregadas pelo excesso de curvatura do tronco, propiciando dores nas costas. Por isso, as mesas de 
trabalho devem estar de acordo com as medidas antropométricas, tanto para o trabalho em pé quanto para o sentado". (Gradjean,1998)

Quando a mesma bancada for utilizada por várias pessoas, sua altura deve ser regulável para atender às diferenças individuais. Em trabalhos essencialmente manuais em pé, as alturas recomendadas variam de acordo com a altura do cotovelo do operador e a natureza do trabalho.

Para atividades como mexer, picar e fritar, as mãos e os cotovelos devem permanecer abaixo do nível dos ombros. Caso a permanência dos braços acima dos ombros seja inevitável, sua duração deve ser limitada, havendo descansos regulares durante sua realização. (Dul e col., 1995)

Várias tarefas exigem movimentos do corpo todo, pois atualmente, apesar de toda automação do trabalho, levantamentos manuais ainda são freqüentes e necessários. Entretanto, respeitar os limites para o levantamento de peso e esclarecer sobre técnicas corretas na execução desta tarefa podem evitar e/ou minimizar futuros problemas de saúde.

A recomendação para o levantamento manual de peso é de $23 \mathrm{~kg}$. Dul e col., 1995). Já a NR-17 do MTB (1999 a) fixa limites máximos de 40 kg para mulheres e $60 \mathrm{~kg}$ para homens. Para mulheres, no artigo 390 da CLT, estabelece limites máximos de $25 \mathrm{~kg}$ para esforço físico ocasional e de $20 \mathrm{~kg}$ para trabalho contínuo, independente da faixa etária. (Brasil, 1994)

Segundo Dul e col. (1995), é necessário que os operadores envolvidos na manipulação de cargas sejam treinados e esclarecidos sobre as técnicas corretas para o levantamento, respeitando os seguintes aspectos: analisar a carga e o local onde esta será removida, considerando a possibilidade de usar uma equipe ou equipamento para o levantamento de peso; manter os pés em posição estável e colocar-se em frente da carga, quando o levantamento for feito sem ajuda; segurar a carga firmemente, usando sempre os dois braços; erguer a carga mantendo a coluna reta, na vertical, conservando-a próxima do corpo, evitando torcer o corpo.

A recomendação para o alcance de braço à de que as bancadas apresentem no máximo, $70 \mathrm{~cm}$ de largura (Laigle e col., 1988). Em relação ao 
alcance de braço acima, a recomendação, para objetos leves, é de $185 \mathrm{~cm}$ para mulheres e $195 \mathrm{~cm}$ para homens. Já os objetos pesados devem ser armazenados em uma altura máxima de $150 \mathrm{~cm}$ e objetos utilizados com freqüência armazenados a uma altura de $70 \mathrm{~cm}$ (Lawson., 1978)

É importante enfatizar que posturas e movimentos incorretos podem provocar lesão e dor muscular a médio prazo, ou, ainda a longo prazo, efeitos como: sobrecarga do aparelho respiratório, formação de edemas e varizes, afecções nas articulações, e particularmente na coluna vertebral.

Além das questões relacionadas à saúde dos operadores várias pesquisas demonstram a relação entre postura e eficiência do operador, já que ela é considerada um importante fator de conforto no trabalho, enquanto que posturas inapropriadas podem tornar-se um perigo para saúde e segurança do trabalhador.(Haslegrave, 1994)

"Parece lógico aceitar as boas condições de trabalho permitem aproveitar melhor as matérias primas e a manufatura de novos produtos, facilitam o desenvolvimento das capacidades dos trabalhadores e repercutem em mudanças positivas nas relações de trabalho, reduzem os riscos e acidentes e geram uma maior produtividade, em conseqüência, contribuem para que as empresas sejam mais competitivas."(Hiba, 1997) 


\section{CAPÍTULO III - METODOLOGIA}

A pesquisa para o desenvolvimento desse projeto foi exploratória, na forma de pesquisa bibliográfica, possibilitando maior conhecimento sobre os temas abordados.

Após o levantamento bibliográfico foram propostos treinamentos referentes a Segurança no Trabalho, para os funcionários de uma Unidade de Alimentação e Nutrição, objetivando despertar a conscientização e capacitação dos indivíduos, para que possam reconhecer as possibilidades de risco, podendo atuar como colaboradores ativos na condução do gerenciamento da qualidade e segurança do ambiente em que estão inseridos.

Os treinamentos propostos se subdividiam em quatro assuntos principais: Acidente de Trabalho, Equipamento de Proteção Coletiva e Individual, Doenças Osteomusculares Relacionadas ao Trabalho e Ergonomia.

Cada assunto deverá ser abordado em um treinamento específico, com datas e horários diferenciados, seguindo uma ordem de aplicação dos treinamentos, pois um treinamento depende do entendimento do treinamento anterior.

Os treinamentos serão desenvolvidos por meio de metodologia participativa e dialógica, enfatizando a relação entre fundamentação teórica sobre os assuntos abordados e a prática vivenciada no dia a dia de trabalho na empresa.

Durante os treinamentos deverão ser realizados trabalhos em grupo com exposição dialogadas dos temas. Poderão ser usadas técnicas diversas, tais como: trabalho em grupo, elaboração de cartazes, tempestade de idéias, dinâmicas de grupo, entre outros.

Como recursos didáticos poderão ser utilizados: cartazes, retroprojetor, TV, vídeo, quadro branco/pincel/apagador, papel pardo/pincel atômico, data show, flip chart e outros. 


\section{CAPÍTULO IV - RESULTADOS E DISCUSSÃO}

\subsection{TREINAMENTOS - A arte de aprender um novo hábito}

Segundo Baptista (1974), treinamento é o processo de desenvolver a aptidão no emprego de métodos seguros de trabalho e na aplicação de práticas seguras durante o desempenho das tarefas.

Os "hábitos de segurança", sejam eles bons ou maus, podem ser interpretados como certo comportamento adquirido, um padrão de ações realizadas de determinada maneira que respeite uma ordem lógica de realização. Uma vez adquirido um hábito para realizar uma tarefa ele se repetirá o tempo todo sem que se pare para pensar seus detalhes. Um hábito adquirido e praticado repetidamente fica profundamente enraizado. Uma vez que esse hábito foi adquirido, praticado e enraizado é extremamente difícil mudá-lo. Quando se trata de bons hábitos isso é positivo, e negativo para os maus hábitos. (Piza, 2001)

O desenvolvimento e ensinamento de um hábito deve se concentrar no fato de ensiná-lo unicamente de forma correta. No início o treinamento tem que ser intensamente prático, com supervisão constante e correção imediata. Se cada repetição correta é um passo a frente, fazê-la de forma errada representa um retrocesso.

Ao permitir desvios nos procedimentos definidos para a estrutura dos hábitos corretos, será aberto um buraco nessa rede, estabelecendo um precedente. Daí em diante o desvio será repetido facilmente em circunstâncias menos favoráveis, assentando as bases para criar um novo e negativo hábito. É nesse momento que o reforço entre em ação. É necessário pensar em alternativas para a reciclagem do conhecimento, como, por exemplo, um tipo de treinamento para refrescar, de vez em quando, a memória e manter viva a cultura dos hábitos de segurança.

Outro ponto que não pode ser esquecido é quando da introdução de novatos na equipe de trabalho. $O$ treinamento em situação real é muito importante, esse treinamento deve ser abordado entre outros aspectos, o 
desenvolvimento das tarefas com segurança. O novo funcionário deve ser instruído sobre a maneira de ser mais produtivo, ter qualidade superior na tarefa executada e como não se expor de maneira desnecessária a riscos que podem ser evitados por medidas de certo modo simples. Dessa forma, a política de segurança da equipe é mantida e disseminada.

\subsubsection{Treinamento I - Acidente de Trabalho}

1 - Identificação:

Local: a ser designado

Data: a ser designado

Tempo Previsto: 1hora e 30 minutos

Público Alvo: Funcionários da UAN

Tema: Acidente de Trabalho

Responsável: a ser designado

3 - Justificativa:

Diante das evidências de que medidas de segurança inadequadas e a falta de treinamento dos operadores aumentam os riscos de acidente de trabalho, faz-se necessária a prevenção desses acontecimentos.

"Medidas de prevenção devem ser adotadas por toda sociedade. Todos nós somos responsáveis pelo que acontece com quem trabalha conosco." (Pastore, 2002)

Segundo Courthiat e col., em estudo realizado na França, em 1983, confirmou as altas taxas de acidentes de trabalho em UANs francesas, constando que durante aquele ano $17 \%$ dos trabalhadores foram vítimas de acidentes de trabalho. Podendo existir ainda, uma sub-declaração de acidentes nos quais não é necessário o afastamento do trabalho.

Diante desses dados, torna-se de extrema importância que os funcionários da UAN tenham conhecimento das possibilidades de riscos de 
acidentes envolvidas nas tarefas que realizam e as maneiras de se evitar esses acidentes .

4 - Objetivos:

3.1 - Objetivo Geral:

Informar aos funcionários da UAN da necessidade de prevenção a acidentes de trabalho e dar embasamento para que estes possam ser evitados.

3.2 - Objetivos Específicos:

Ao final do treinamento os funcionários deverão estar aptos a:

- Reconhecer os tipos de riscos de acidentes presentes na UAN;

- Reconhecer os locais e procedimentos onde há risco de acidentes de trabalho;

- Saber utilizar métodos de prevenção a acidentes de trabalho;

- $\quad$ Promover trabalho com segurança nas unidades onde trabalham.

5 - Metodologia e Recursos Didáticos:

O treinamento será desenvolvido por metodologia participativa e dialógica, enfatizando a relação entre a fundamentação teórica e o trabalho em uma UAN.

Durante o treinamento serão aplicados dinâmica de grupo, técnica da ‘tempestade de idéias' e trabalho em grupo.

Recursos didáticos a serem utilizados: cartazes com desenhos ou gravuras; quadro branco/pincel/apagador; papel pardo/pincel atômico; balões coloridos; cartaz do "Programa de Disseminação de Conhecimentos Sobre Segurança e Saúde no Trabalho".

6 - Desenvolvimento: 
O Treinamento I, terá início com uma dinâmica de grupo, com o objetivo de propiciar um primeiro contato e entrosamento das pessoas que fazem parte do grupo.

Sugestão de Dinâmica: Balões Coloridos (Anexo D)

Após a dinâmica será ministrada o treinamento com aula expositiva, apresentada pelo palestrante, elaborada a partir do Referencial Teórico da presente monografia, Capítulo II, Item 2.2, páginas de 06 à 16.

Durante a aula expositiva deverá ser abordado o conceito de Acidente de trabalho e aplicações, direcionando para área de refeições coletivas; descrever os riscos ambientais presentes nas UAN, conceituando e apresentando exemplos práticos; categorizar os riscos ambientais presentes e discorrer sobre cada categoria, exemplificando. Enfatizar os métodos de prevenção à acidentes e doenças profissionais dentro da UAN.

Em unidades que possuam o PPRA, os dados das medições contidas neste podem ser citados a nível de exemplificação.

Sugestão: Durante a aula expositiva usar cartazes com desenhos e/ou colagens de figuras demonstrando cada tipo de risco à medida em que forem citados.

Ao término da aula expositiva, sugere-se a utilização a Técnica de Tempestade de Idéias, com o tema: Como evitar acidentes de trabalho em nosso dia-a-dia? (Anexo E)

Para avaliar o entendimento do treinamento, sugere-se a divisão desses em 2 grupos. Cada grupo deverá escolher um líder. Será distribuído para cada grupo parte do material do "Programa de Disseminação de Conhecimentos sobre Segurança e Saúde no Trabalho", um grupo ficará com a forma CERTA de trabalhar e o outro com a forma ERRADA, cada grupo deverá analisar os quadros do material e identificar o motivo da classificação. O líder deverá apresentar para o resto da turma as conclusões da equipe.(Anexo F)

Ao término do treinamento, o palestrante deverá avaliar o treinamento aplicado, respondendo as seguintes questões: 
- Os recursos utilizados foram apropriados?

- Qual foi o benefício dos recursos utilizados?

- Podem ser melhorado?

- O tempo de duração atingiu o pré-determinado?

4.1.2 Treinamento II - Equipamento de Proteção Coletiva (EPC) e Equipamento de Proteção Individual (EPI)

1 - Identificação:

Local: a ser designado

Data: a ser designada

Tempo Previsto: 1 hora e 30 minutos

Público Alvo: Funcionários da UAN

Tema: Equipamento de Proteção Coletiva (EPC) e Equipamento de Proteção Individual (EPI)

Responsável: a ser designado

2 - Justificativa:

Os EPC e EPI constituem-se em dispositivos utilizados para proteger os trabalhadores dos riscos de acidentes inerentes aos processos de trabalho.

Como visto no Treinamento I, alguns riscos de acidentes só podem ser neutralizados ou minimizados com a adoção dos EPC e EPI. Com base nessa constatação, faz-se necessário o treinamento sobre esses equipamentos de proteção, para que os trabalhadores tenham consciência de sua importância e a forma correta de sua utilização.

3 - Objetivos:

3.1 - Objetivo Geral:

Apresentar aos funcionários da UAN os benefícios da utilização correta dos EPC e EPI para a prevenção de acidentes de trabalho. 


\section{2 - Objetivos Específicos:}

Ao final do treinamento os funcionários deverão estar aptos a:

- Diferenciar EPC de EPI;

- Identificar os riscos que podem ser evitados com a utilização desses equipamentos;

- Reconhecer os locais e/ou atividades que necessitam a utilização desses equipamentos;

- Distinguir qual equipamento que deve ser utilizado, para cada atividade que determine risco de acidente no processo de trabalho.

4 - Metodologia e Recursos Didáticos:

O treinamento será desenvolvido por meio da metodologia participativa e dialógica.

Durante o treinamento serão aplicados dinâmica de grupo e trabalho em grupo.

Recursos didáticos a serem utilizados: quadro branco/pincel/apagador; alguns EPI e EPC (ou representação destes) e maquetes das áreas de trabalho.

5- Desenvolvimento:

O treinamento II, deverá ter início com uma dinâmica de grupo, para facilitar a aproximação e integração dos participantes.

Sugestão de Dinâmica: Cosme e Damião (Anexo G)

Ao término da dinâmica, será iniciada uma aula expositiva, sobre EPI e EPC, contido na presente monografia no capítulo II, itens 2.3, páginas 16 e 17 . Para melhor exemplificação deverá ser retomado o item 2.2, que trata sobre acidente de trabalho (página de 6 à 16). 
Durante a aula expositiva serão abordados temas como: diferença entre EPI e EPC, como e em quais situações eles são necessários, quais os riscos de sua não utilização ou sua utilização indevida.

Após a aula expositiva, sugere-se a prática de um trabalho em grupo para fixação do conteúdo e avaliação do entendimento dos funcionários. Nessa avaliação, os funcionários deverão relacionar os EPC e EPI aos locais ou situações em que devam ser utilizados. (Anexo $\mathrm{H}$ )

Ao término do treinamento, o palestrante deverá avaliar o treinamento aplicado, respondendo as seguintes questões:

- Os recursos utilizados foram apropriados?

- Qual foi o benefício dos recursos utilizados?

- Podem ser melhorado?

- Duração?

4.1.3 Treinamento III - Lesão por Esforços Repetitivos (LER) Doenças Osteomusculares Relacionadas ao Trabalho (DORT)

1 - Identificação:

Local: a ser designado

Data: a ser designada

Tempo Previsto: 1 hora e 30 minutos

Público Alvo: Funcionários da UAN

Tema: Doenças Osteomusculares Relacionadas ao Trabalho (DORT)

Responsável: a ser designado

2 - Justificativa:

Os trabalhos realizados em uma UAN são caracterizados por movimentos repetitivos por longos períodos de tempo e os trabalho em posição em pé, constituem as maiores causas de LER/DORT.

"Se a pessoa trabalha fazendo movimentos repetitivos, durante várias horas, ou com a musculatura tensa durante horas, todo o sistema pode entrar 
em colapso, resultando: fadiga muscular, alteração da sensibilidade, sensação de peso, perda de controle dos movimentos, formigamento e dor. Esses sintomas podem significar, isolada ou associadamente, a existência de tendinite, tenossinovite, neurite, entre outros. O aparecimento de LER/DORT é gradativo, os sintomas não aparecem de repente." (Ministério da Saúde, 2001)

Diante desses fatos, faz-se necessário a abordagem preventiva para LER/DORT em funcionários da UAN.

3 - Objetivos:

3.1 - Objetivo Geral:

Propiciar aos funcionários da UAN um conhecimento geral sobre LER/DORT e métodos de prevenção para a essa doença profissional.

3.2 - Objetivos Específicos:

Ao final do módulo os funcionários devem estar aptos:

- Saber o que é LER/DORT;

- Localizar as tarefas ou funções onde existem risco de LER/DORT;

- Maneiras de prevenção a essas doenças;

- O que fazer quando existe a suspeita de LER/DORT.

4 - Metodologia e Recursos Didáticos:

O treinamento será desenvolvido por metodologia participativa e dialógica, interrelacionando a teoria com a prática no dia-a-dia da UAN.

Durante o treinamento serão realizados teste com os funcionários e técnica de aquecimento e alongamento .

Recursos didáticos utilizados: Peça de borracha do membro superior esquematizando o funcionamento do músculo e retroprojetor.

5 - Desenvolvimento:

Para a introdução do Treinamento III, sugere-se a utilização de um membro superior do corpo humano (braço e ante-braço), demostrando como 
ocorrem os movimentos dos braços e demonstrando como os movimentos repetitivos levam ao surgimento de LER/DORT.

Após a demonstração dos movimentos, será realizada a aula expositiva e participativa. Nessa aula deverá ser abordado o conceito de LER/DORT, fatores de risco, formas de prevenção e tratamento e reabilitação, de acordo com o capítulo II, item 2. 5, páginas 18 à 30 da presente monografia.

Sugere-se a utilização do teste "Você já se flagrou?" contido no Manual n 106 do Ministério da Saúde, páginas 10 à 12. O teste propiciará aos funcionários análise dos sinais de alerta que o organismo apresenta e, que podem não ser percebidos no cotidiano. Esse teste pode ser apresentado utilizando o retroprojetor. (Anexo I)

Deve-se dar ênfase à atividade física, ao alongamento e ao relaxamento para a prevenção das LER/DORT. Na página da internet http://openlink.br, há uma seqüência de exercícios (com animação) para a prevenção da LER/DORT. Sugere-se a utilização deste material durante o treinamento. (Anexo J)

Para finalizar o treinamento, convide todos os participantes a acompanhar os exercícios de aquecimento e alongamento apresentados, priorizando a correta execução do exercício.

Com base nas atividades desenvolvidas o longo do treinamento o palestrante deverá avaliar o treinamento aplicado respondendo as seguintes questões:

Os recursos utilizados foram apropriados?

Qual foi o benefício dos recursos utilizados?

Podem ser melhorado?

Duração?

\footnotetext{
4.1.4 Treinamento IV - Ergonomia

1 - Identificação:
} 
Local: a ser designado

Data: a ser designada

Tempo Previsto: 1 hora e 30 minutos

Público Alvo: Funcionários da UAN

Tema: Ergonomia

Responsável: a ser designado

2 - Justificativa:

"O alvo da ergonomia á a adequação das condições de trabalho às capacidades e realidades da pessoas que trabalha."(Grandjean, 1998)

Com um planejamento adequado em uma UAN é possível evitar movimentos desnecessários por parte dos funcionários, minimizando sua fadiga, diminuindo a ocorrência de LER/DORT.

3 - Objetivos:

3.1 - Objetivo Geral:

Informar aos funcionários qual é a melhor maneira de dispor os equipamentos dentro de uma UAN e posturas adequadas a serem assumidas, a fim de evitar esforços desnecessários.

3.2 -Objetivos Específicos:

Ao final do treinamento os funcionários deverão estar aptos a:

- Saber qual é a melhor configuração do local de trabalho;

- Evitar sobrecarga da musculatura corporal devido a posições inadequadas;

- Saber os limites de levantamento de peso e técnicas corretas para execução dessa tarefa;

- Saber que posturas e movimentos incorretos podem provocar lesão e dor muscular, sobrecarga do aparelho respiratório, edemas, varizes, entre outros. 
3 - Metodologia:

O treinamento será desenvolvido por metodologia participativa e dialógica, enfatizando a relação entre a fundamentação teórica e as condições de trabalho da UAN.

Durante o treinamento serão utilizadas duas dinâmicas de grupo.

Recursos didáticos a serem utilizados: cartaz com o desenho do burro, papel colorido, durex ou fita crepe, papel manilha pardo, recortes de revista, desenhos coloridos e lápis de cor ou pincéis coloridos.

4 - Desenvolvimento:

O treinamento IV, terá início com uma dinâmica de grupo, com o objetivo de demonstrar a importância do trabalho em grupo.

Sugestão de dinâmica: O Rabo do Burro (Anexo K)

Após a dinâmica será ministrado uma aula expositiva, apresentada pelo palestrante, elaborada a partir do referencial teórico da presente monografia, Capítulo II, Item 2.6, página 30 à 36.

Durante a aula expositiva deverá ser abordado o conceito e benefícios da Ergonomia, a importância do trabalho em grupo para evitar sobrecarga de trabalho e a importância da adoção posturas corretas.

Ao término da aula expositiva, sugere-se a dinâmica 'A Linha da Vida', como forma de avaliação do entendimento do treinamento. (Anexo $L$ )

Com base nas atividades desenvolvidas o longo do treinamento 0 palestrante deverá avaliar o treinamento aplicado respondendo as seguintes questões:

Os recursos utilizados foram apropriados?

Qual foi o benefício dos recursos utilizados?

Podem ser melhorado?

Duração? 


\section{CAPÍTULO V - CONSIDERAÇÕES FINAIS}

A responsabilidade pela elaboração e implementação do Programa de Prevenção de Riscos Ambientais (PPRA) é única e total do empregador, devendo ainda zelar pela sua eficácia, sendo sua profundidade e abrangência dependentes das características dos riscos e das necessidades de controle.

Todas as empresas que possuam empregados, independente do tamanho e grau de risco, desde que regidos pela CLT são obrigadas a implantar o Programa de Controle Médico de Saúde Ocupacional (PCMSO).

É também de responsabilidade do empregador o fornecimento de equipamento de proteção quando os riscos ambientais se apresentarem acima dos limites de tolerância. Quando se pensa nos equipamentos de proteção coletiva vem à mente investimentos altos de retorno duvidoso. Normalmente, isso raramente ocorre, pois em se tratando de técnicas prevencionistas, as idéias que maior resultado apresentam são as que conciliam baixo custo e alta durabilidade às condições ideais de proteção. Outra verdade inquestionável é a de que os detentores do maior conhecimento de soluções ideais de produção são os próprios trabalhadores que são expostos aos riscos. Comprove-se isso facilmente, lembrando-se dos resultados colhidos com a criação dos grupos de qualidade.

A empresa é obrigada a fornecer aos empregados gratuitamente o EPI adequado ao risco e em perfeito estado de funcionamento e conservação, treinar o empregado quanto ao seu uso adequado e tornar obrigatório o seu uso.

É fundamental a adoção de uma política prevencionista dentro das organizações. $O$ acidente de trabalho envolve perda para as pessoas, para as empresas e para o Estado. Os custos de manutenção desse número 
exagerado de acidentes são elevados. Mas esses custos só serão reduzidos, no momento em que as empresas entenderem que a prevenção é economicamente mais viável do que os custos acarretados com os acidentes e doenças profissionais.

Atualmente, dentre os países membros da Organização Internacional do Trabalho (OIT), somente o Brasil adota o critério de pagamento de adicional de insalubridade e periculosidade. Esses adicionais trouxeram muito mais malefícios do que benefícios para a vida laboral no país. A empresa ao pagar o adicional insalubridade $\mathrm{e}$ periculosidade exime-se de qualquer responsabilidade sobre o bem estar e segurança de seus funcionários.

Felizmente, dentro das esferas empresariais, governamentais e sindicais do país essa mentalidade está mudada. Os representantes dessas classes não defendem mais esses 'benefícios' e estão procurando definir critérios técnicos preventivos adequados.

O sucesso das campanhas de prevenção de acidentes depende, em grande parte, da capacidade das suas mensagens transmitirem de modo claro e direto que o atendimento das necessidades humanas traz vantagens econômicas para quem investe na redução dos riscos profissionais, além de ser eticamente valorizado.

O trabalho em uma UAN é caracterizado como um processo de produção que utiliza intensamente sua mão-de-obra, sendo considerada por muitos como uma atividade árdua, de ritmo intenso, com posturas forçadas mantidas por longo períodos. Em virtudes dessas características, o trabalho em uma UAN, é considerado por muitos funcionários como ao algo provisório. Somente uma minoria de funcionários do setor desejam fazer carreira nesse tipo de atividade.

As campanhas preventivas aplicadas nas UAN devem considerar todos os fatores envolvidos no ambiente laboral: agentes ambientais, ergonomia e o risco de desenvolvimento de LER/DORT induzido pelo 
trabalho repetitivo. Ao minimizar a influência desses fatores no ambiente de trabalho promoverá a melhoria na qualidade de vida dos funcionários e conseqüente, melhora no produto final.

Essas campanhas devem ser constantes. Existem vários métodos possíveis para a campanha, entre eles estão os treinamentos, que devem ser aplicados de forma dinâmica e participativa, para facilitar o processo de aprendizagem do curso pelos funcionários. Os treinamentos não terminam quando acaba a aula expositiva, devem decorrer através do desenvolvimento de constantes análises da aplicação dos métodos preventivos no dia a dia laboral. Deve-se sobretudo, buscar o recurso do treinamento de acordo com a necessidade de reciclagem dos funcionários ou admissão de novos, objetivando a manutenção da política de segurança.

Em suma, o treinamento é uma ferramenta essencial para a manutenção da política de qualidade laboral em uma Unidade de Produção. 
Anexo A

No art. 157 da CLT são estabelecidas as competências das empresas:

"I - cumprir e fazer cumprir as normas de segurança e medicina do trabalho;

II - instruir os empregados, através de ordens de serviço, quanto às precauções a tomar no sentido de evitar acidentes de trabalho ou doenças ocupacionais;

III - adotar as medidas que Ihes sejam determinadas pelo órgão regional competente;

IV - facilitar a fiscalização pela autoridade competente."

No art. 158, são estabelecidos as atribuições dos trabalhadores:

"Cabe aos empregados:

I - observar as normas de segurança e medicina do trabalho, inclusive as instruções de que trata o item II do artigo anterior;

II - colaborar com a empresa na aplicação dos dispositivos do capítulo;

Parágrafo único. Constitui ato faltoso do empregado a recusa injustificada:

a) à observância das instruções expedidas pelo empregador na forma do item II do artigo anterior;

b) ao uso dos equipamentos de proteção individual fornecidos pela empresa." 


\section{Anexo B}

"Acidente do trabalho é o que ocorre pelo exercício do trabalho a serviço da empresa ou pelo exercício do trabalho dos segurados referidos no inciso VII do art. 11 desta lei, provocando lesão corporal ou perturbação funcional que cause a morte ou a perda ou redução, permanente ou temporária, da capacidade para o trabalho."

O art.20 amplia o conceito previdenciário de acidente de trabalho:

"Consideram-se acidentes do trabalho, nos termos do artigo anterior, as seguintes entidades mórbidas:

I - doença profissional, assim entendida a produzida ou desencadeada pelo exercício do trabalho e constante da respectiva relação elaborada pelo Ministério do Trabalho e da Previdência Social.

II - doença do trabalho, assim entendida a adquirida ou desencadeada em função de condições especiais em que o trabalho é realizado e com ele se relacione diretamente, constante da relação mencionada no inciso I."

Por sua vez, o art. 21 amplia o conceito previdenciário de acidente de trabalho, considerando como tal:

"I - o acidente ligado ao trabalho que, embora não tenha sido a causa única, haja contribuído diretamente para a morte de segurado, para a redução ou perda da sua capacidade para o trabalho, ou produzido lesão que exija atenção médica para a sua recuperação;

II - 0 acidente sofrido pelo segurado no local e no horário de trabalho, em conseqüência de:

a) ato de agressão, sabotagem ou terrorismo praticado por terceiro ou companheiro de trabalho;

b) ofensa física intencional, inclusive de terceiro, por motivo de disputa relacionada ao trabalho;

c) ato de imprudência, de negligência ou de imperícia de terceiro ou de companheiro de trabalho; 
d) ato de pessoas privada do uso da razão;

e) desabamento, inundação, incêndio e outros casos fortuitos ou decorrentes de força maior;

IV - o acidente de trabalho sofrido pelo segurado, ainda que fora do local de trabalho:

a) na execução de ordem ou na realização de serviço sob a autoridade da empresa;

b) na prestação espontânea de qualquer serviço à empresa para the evitar prejuízo ou proporcionar proveito;

c) em viagem a serviço pela empresa

d) no percurso da residência para o local de trabalho ou deste para aquela, qualquer que seja o meio de locomoção utilizado. 


\section{Anexo C}

Limites de tolerância ( Anexo 1 - NR-15)

\begin{tabular}{|c|c|}
\hline Nível de ruído dB (A) & Máxima exposição diária permissível \\
\hline 85 & 8 horas \\
\hline 86 & 7 horas \\
\hline 87 & 6 horas \\
\hline 88 & 5 horas \\
\hline 89 & 4 horas e 30 minutos \\
\hline 90 & 4 horas \\
\hline 91 & 3 horas e 30 minutos \\
\hline 92 & 3 horas \\
\hline 93 & 2 horas e 40 minutos \\
\hline 94 & 2 horas e 40 minutos \\
\hline 95 & 2 horas \\
\hline 96 & 1 hora e 45 minutos \\
\hline 98 & 1 hora e 15 minutos \\
\hline 100 & 1hora \\
\hline 102 & 45 minutos \\
\hline 104 & 35 minutos \\
\hline 105 & 30 minutos \\
\hline 106 & 25 minutos \\
\hline 108 & 20 minutos \\
\hline 110 & 15 minutos \\
\hline 112 & 10 minutos \\
\hline 114 & 8 minutos \\
\hline 115 & 7 minutos \\
\hline
\end{tabular}

A tabela, extraída da NR-15, apresenta os limites de tolerância para ruído contínuo ou intermitente. 
Anexo D

Dinâmica de grupo: Balões coloridos

Objetivo: propiciar um primeiro contato e entrosamento das pessoas que fazem parte do grupo com o qual irá trabalhar.

Instruções:

- O palestrante deverá distribuir uma bexiga vazia e um pedaço de papel pequeno em branco para cada participante;

- Deverá solicitar às pessoas que escrevam três características pessoais no papel, conquanto que a partir delas o grupo possa identificá-la. Em seguida, todos deverão dobrar o papel e colocá-lo na bexiga;

- Cada funcionário deverá encher sua bexiga e, quando todas estiverem cheias, os participantes deveram jogar as bexigas um para o outro aleatoriamente, durante alguns minutos;

- Em seguida, o palestrante deverá dar sinal de parada, e neste momento, cada um deverá pegar a bexiga que estiver na sua frente e estourar;

- Cada participante deverá ler o papel que estava na bexiga, procurar a pessoa que escreveu e se apresentar a ela.

Discussão:

O palestrante abre para discussão sobre as dificuldades encontradas para localizar a outra pessoa, as características pessoais mais fáceis de identificar e qual tarefa mais fácil de executar. 


\section{Anexo E}

Tempestade de Idéias:

Essa técnica é utilizada para resolução de problemas onde os participantes são incentivados a comunicar quaisquer idéias que venham à mente, sem medo de serem criticados. Portanto, o seu princípio básico é libertar o indivíduo do julgamento crítico e da avaliação os quais tendem a reduzir ou impedir a produção de idéias e a imaginação.

A avaliação de idéias não ocorre na fase de produção e sim em uma etapa posterior, após um grande número de idéias alternativas terem sido levantadas.

1- Aspectos a serem observados ao aplicar a técnica:

- Não criticar ou avaliar nenhuma das idéias produzidas. As idéias devem ser apresentadas livremente e sem julgamento;

- Aceitar todos os tipos de idéias, as 'loucas', as bem humorada, as estranhas, incomuns ou inusitadas, pois podem dar origem a outras idéias;

- Enfatizar a quantidade de idéias. Quanto mais idéias apresentadas, maiores as chances de conseguir boas idéias;

- Procurar combinar ou aperfeiçoar idéias. Nenhuma idéia apresentada por uma pessoa pertence unicamente a ela. Elas são propriedade de todos e podem ser usadas para gerar novas idéias.

7 - Organização do ambiente e da participação do grupo:

- os participantes devem se distribuir em círculo, de modo a facilitar a participação ou integração;

- O problema pode ser escolhido pelo grupo ou ser sugerido pelo orientador; 
- As idéias devem ser comunicadas à medida em que forem emergindo. Não é necessário que cada um espere sua vez para falar.

- Solicitar uma rodada em círculo, para que todos participem;

- As idéias podem ser formadas com a combinação ou modificação de outras já apresentadas;

- Todas as respostas devem ser copiadas no quadro ou em papel pardo, colado nas paredes da sala de aula;

- A tempestade de idéias deve ser rápida, durando no máximo 15 minutos.

8 - Trabalho a partir das idéias levantadas:

- Identificar as melhores idéias seguindo padrões ou critérios de análise elaborados com os participantes;

- Definir critérios de análise como: aplicabilidade, custo, utilidade, tempo, beleza, abrangência, etc.

- Atribuir pontos a cada critério, utilizando, por exemplo uma escala de 3 pontos, onde 1 será insatisfatório, 2 razoável e 3 satisfatório;

- Julgar cada idéia tendo em vista os critérios utilizados, somando a pontuação;

- Selecionar a combinação de idéias consideradas melhores e reescrevê-las, se for necessário uma nova redação;

- Abrir para comentários.

4 - Vantagens da Técnica

- Facilita a emergência de soluções variadas para os problemas trabalhados;

- Possibilita a escolha de soluções mais adequadas;

- Desenvolve o potencial criativo e crítico;

- Torna as pessoas mais participativas e confiantes em sua capacidade de lidar com problemas. 


\section{5 - Restrições da Técnica}

- Não se aplica a todos os tipos de problema;

- A falta de conhecimento dos participantes a respeito da área ou assunto que envolve o problema.

\section{Anexo F - CERTO E ERRADO}

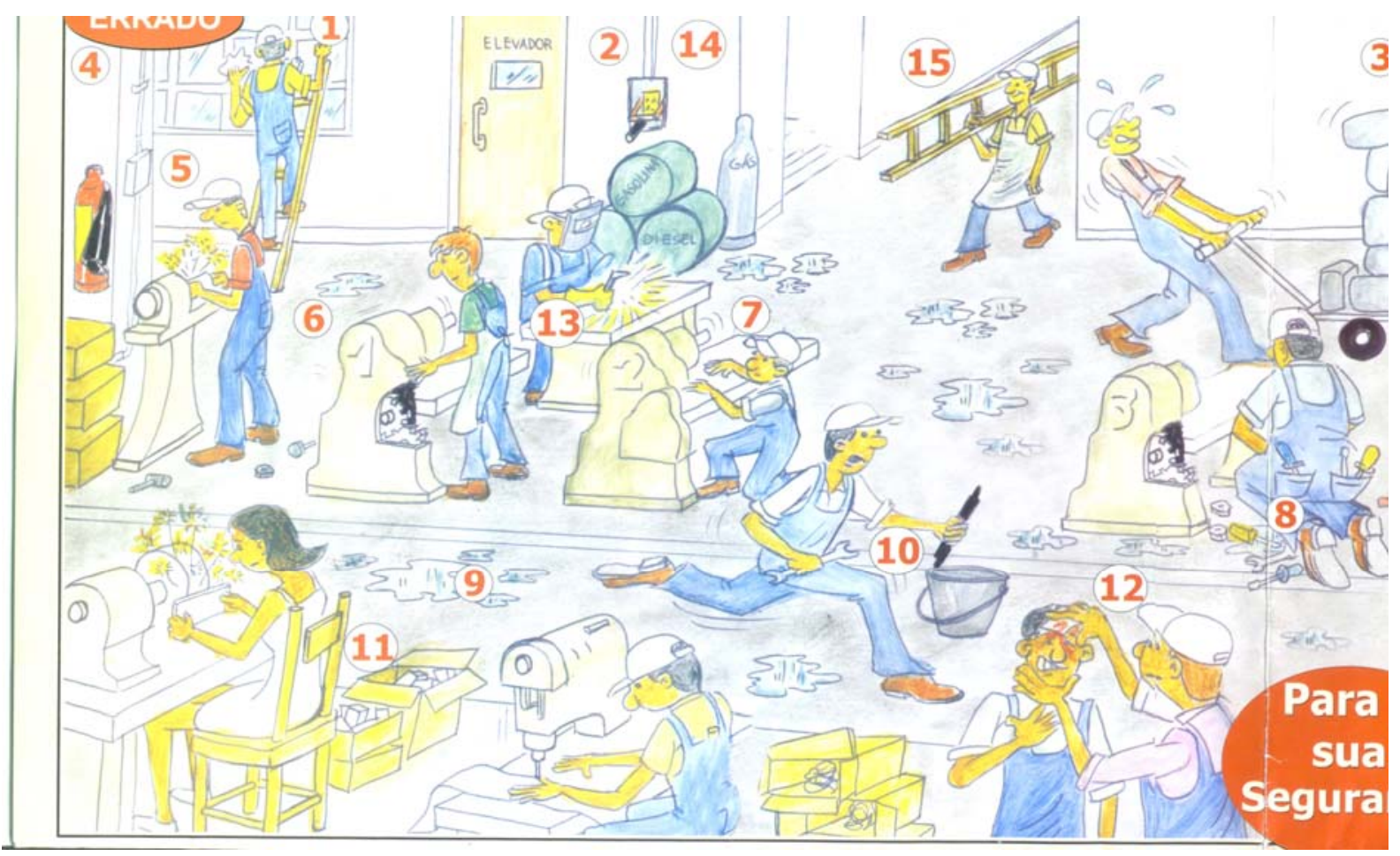




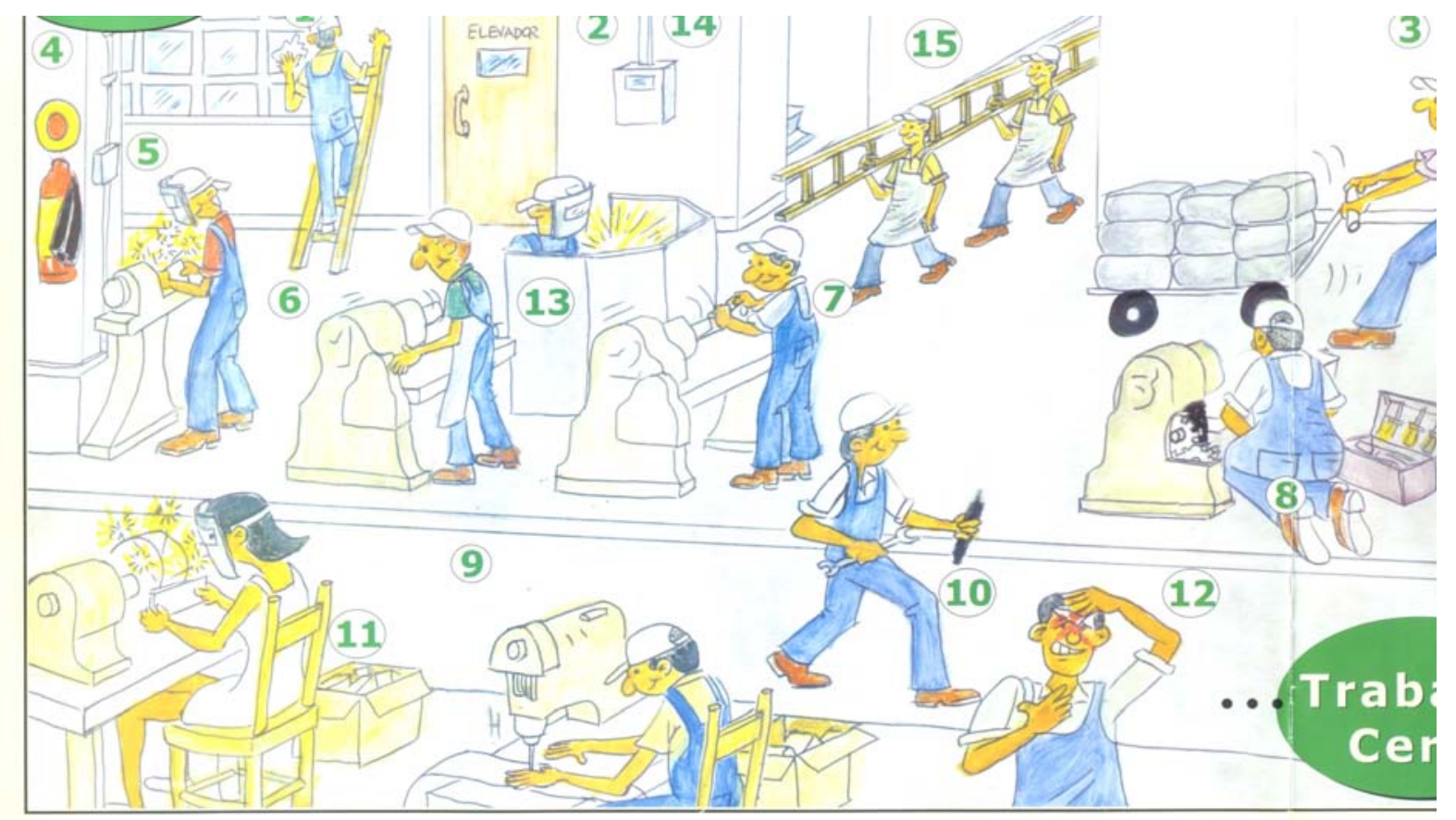

Anexo G

Dinâmica de grupo: Cosme e Damião

Objetivo:

Facilitar a aproximação dos participantes, integrando-os no processo de aprendizagem do grupo.

Instrução:

O palestrante deverá solicitar que os participantes se dividam em duplas, preferencialmente agrupando as pessoas que tenham menos contato entre si.

Em seguida o palestrante passará a seguinte instrução: "Vocês deverão conversar entre si durante cinco minutos sobre o tema 'O MEU DIA DE ONTEM'. Procurem dividir o tempo. Cada um deve observar o outro ao máximo. 
Após decorridos os cinco minutos, o palestrante dá a seguinte ordem: "Agora, cada um de vocês terá um minuto para representar (dramatizar) o outro. Vocês devem caracterizar o outro da forma mais completa possível.

Procurem representar a forma de falar, a postura física, os tiques, enfim incorporar o outro".

Dar tempo para que cada pessoa se apresente e abrir comentários.

Discussão:

O palestrante deverá solicitar que cada participante avalie o que sentiu quando representado e quais dificuldades e facilidades sentiu quando representou o outro. Como o grupo sentiu a atividade, em que aspectos ela facilitou o entrosamento do grupo e o auto conhecimento de cada participante.

Anexo $\mathrm{H}$

Trabalho de Grupo: EPC E EPI

Objetivo: Fixação do conteúdo demonstrado no treinamento.

Instrução:

- Dividir os participantes em dois grupos, cada grupo receberá uma história, delimitar tempo para a leitura e assimilação;

- Deverão ser montadas duas bancadas: a primeira bancada contendo os EPI e EPC, quando não for viável os equipamentos, coloca-se desenhos ou maquetes destes. E outra bancada, onde deverão estar 
dispostas maquetes ou desenhos dos locais ou situações onde esses EPI ou EPC devem ser utilizados;

- O palestrante deve dar a seguinte instrução: "cada grupo recebeu uma estória, um membro do grupo deve lê-la em voz alta, quando aparecer uma situação em que seja necessário a utilização de um EPI ou EPC, um membro do grupo deverá dirigir-se a bancada e pegar o equipamento adequado à situação. Em seguida, o participante irá até a outra bancada e pegará a maquete ou desenho que represente o local onde o EPI ou EPC é necessário e agrupá-los, em um local determinado para o grupo. O Grupo I começará o jogo contando sua estória e agrupando o material que achar necessário, em seguida o Grupo II."

- Será vencedor o grupo que conseguir agrupar de maneira correta o maior número de equipamentos. Deverá ser seguida a ordem em que a situação apareça na história.

- Material necessário: botas e luvas de borracha, luva de malha de aço, luva térmica, casaco térmico, corrimão de escada, balde, câmara fria, escadaria, faca.

História I: Natal

"É natal, toda a família se encontra reunida para festejarmos a grande festa, e juntos esperarmos o Papai Noel,..., temos muitos preparativos ainda por fazer. A primeira coisa é deixar a casa limpa, muito limpa!!! Então resolvemos lavar tudo, pegamos o balde e jogamos água* e sabão por toda parte no chão, nas paredes, na cozinha. Ah, já ia esquecendo a lareira, afinal não queremos que o Papai Noel fique sujo!!!

Depois que a casa ficou limpinha, resolvemos preparar o banquete para a ceia logo mais à noite. A grande atração da ceia é o perú de Natal, então começamos a prepará-lo. Minha tia Maria disse que fica ótimo rechear o perú com fatias finas de bacon. Minha mãe pegou aquela faca enorme, que até parece instrumento de açogueiro e fatiou o bacon *. Recheou o bichão e o colocou no forno.... a todo instante tinha 
um curioso observando o perú mudar de coloração e a pele ficar crocante, super crocante!!! Ao todo devem ter aberto e fechado o forno* umas mil vezes.... até que minha mãe ficou brava e tirou todos da cozinha.

Subimos a grande escadaria* da casa que leva ao andar superior onde se localizam os quartos, ficamos lá brincando até a hora da tão esperada ceia, finalmente comemos o perú de Natal e recebemos milhões de presentes deixados pelo Papai Noel."

História II:

"É domingo! O sol invade a cidade! Dia propício para um pique nique. Mais para fazermos um pique nique, temos que preparar a cesta com as guloseimas.... frutas, bolo, pães, frango assado, farofa!!! Então temos que comprar o frango para prepará-lo. Corri até o açougue e o menino que estava tomando conta me disse para pegar o frango que estava no fundo de uma câmara fria *. Peguei o frango e corri para casa, minha mãe já estava esperando com a faca na mão para picá-lo *. Após picado e temperado, minha mãe colocou o frango no forno e foi preparar a farofa e demais comidas para o pique nique. No meio de tantos preparativos ela se esqueceu do frango,..., quando abriu o forno * 0 coitado já estava quase queimado. Ainda bem que não queimou o frango todo, somente algumas partes..... Colocamos o que restou do frango na cesta e saímos de carro a caminho do parque, ainda tínhamos a tarde toda para curtir o sol e natureza. Foi um dia maravilhoso!!!"

Discussão:

- Um representante de cada grupo deverá descrever quais EPI e EPC foram utilizados nos textos e situações em que eram necessários.

- O que facilitou ou dificultou a descoberta dos equipamentos na estória?

- Como essa vivência se reproduz no nosso dia-a-dia? 
Ixxix 
FAÇA O TESTE. VOCÊ JÁ SE FLAGROU:
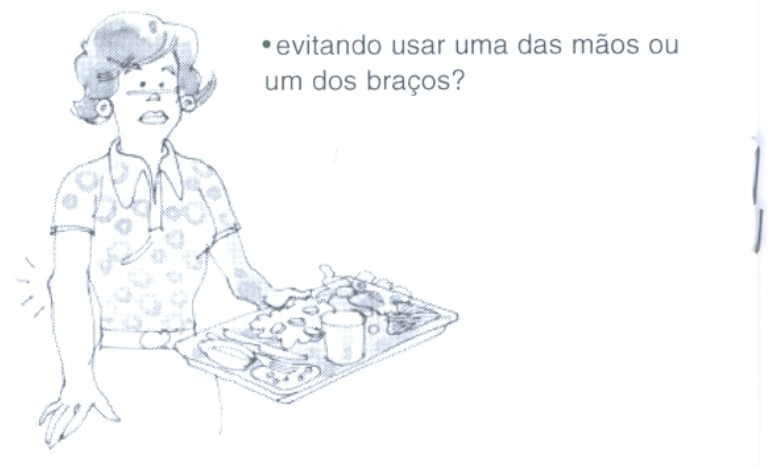

0

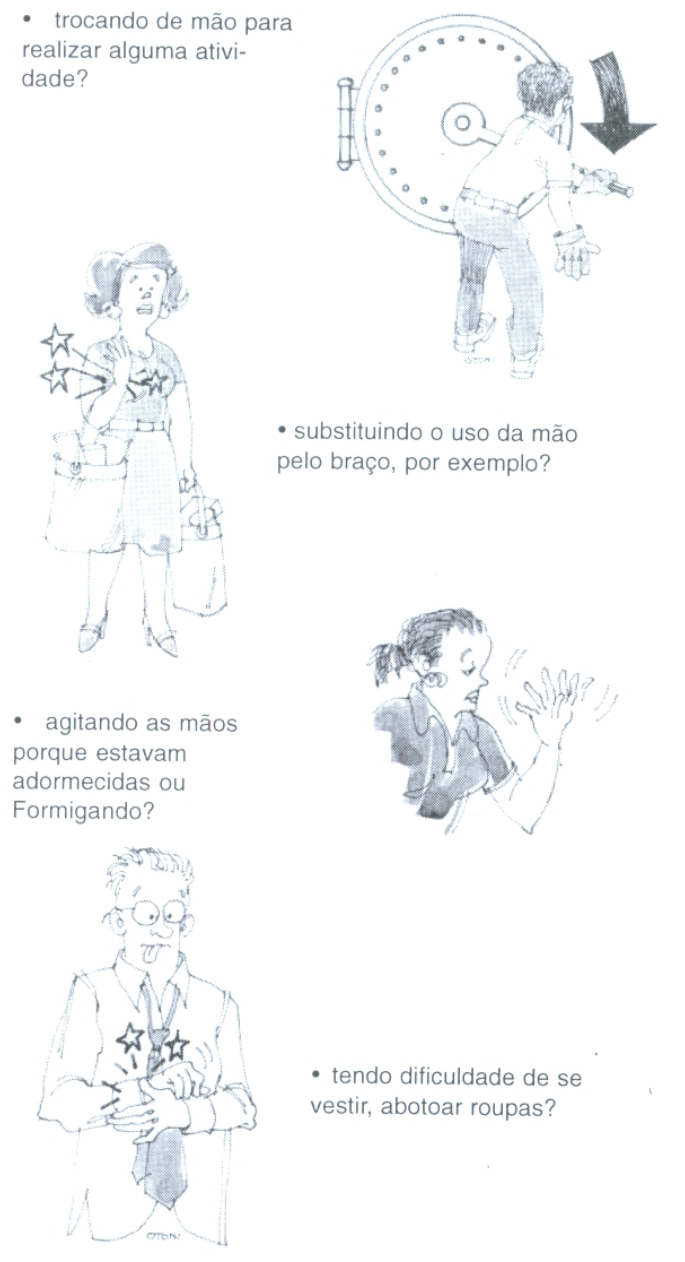




\section{Anexo J - Exercícios}

LER/DORT , COMO PREVENIR...

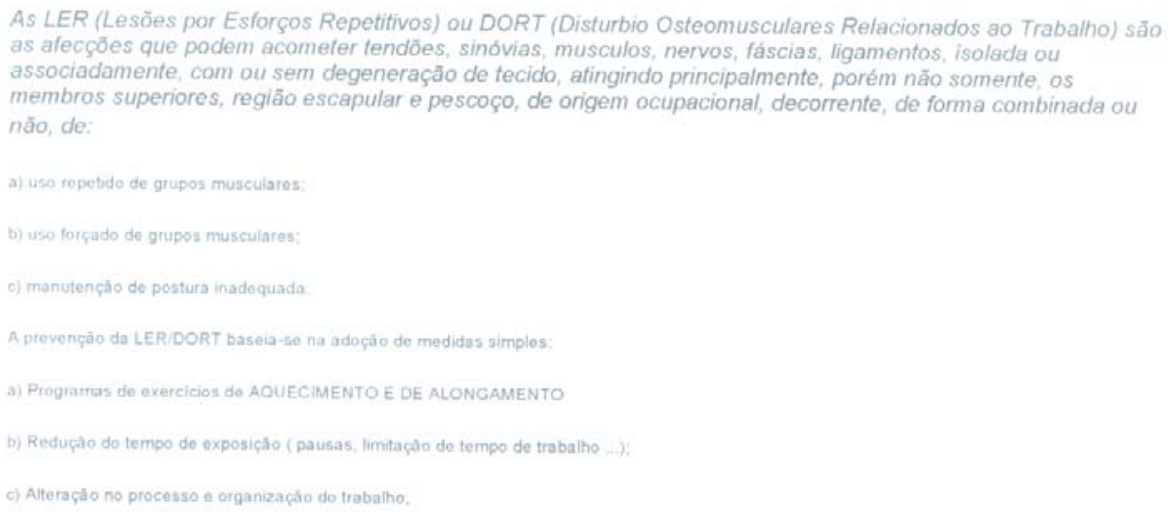

d) Adeququaça a as caractoristicas dos trabailhadores de müquinas, mobiliário, dispositivos, equipamentos e forramantas do trabatho

Exercícios para a prevenção da LER.

AQUECIMENTO

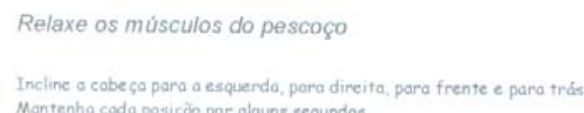
Mantenho coda posiçào por alquns segundos

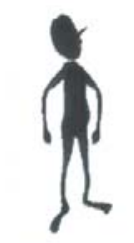

Rolagem de ombro

Com as braços soltos e com as măos apontando para baixo, execute um movimento giratório nos ombros para frente, por três vezes, e para trás. por três vezes.

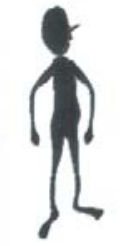

Rotaçăo de antebraço

Levante os braços estirodos, com as palmas das mãos voltados para cima. até a altura dos ombros. Gine os braços lentarnente para dentro até que o dorso das mäos fiquem de frente um para outro, Gine os bracos novamente. 


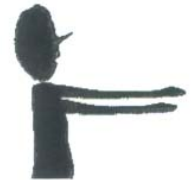

Rotação de punho

Com os braços retos e para os lados, gire lentamente as mão em círculo, trabalhando os punhos.

Alongamento e compressão dos dedos

Com as mãos para a frente $e$ as palmas voltadas para baixo, estire os dedos - tanto quanto puder, mantenha-os nessa posição por alguns segundos: em seguida feche as mãos com toda força.

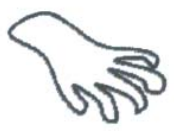

Flexões das pontas dos dedos

Com a mão direita estendida, dedos juntos e palma voltada para baixo. force os dedos contra a palma da mão esquerda, mantenha a posição por alguns segundos e solte-os suavemente. Repita as flexões nos dedos do outra mão e assim por diante.

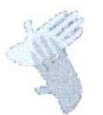

\title{
ALONGAMENTO
}

Todos os exercícios devem ser realizados na posição sentada, com os pés bem apoiados no chão a coluna deve estar afastada do encosto e ereta, a duração de cada exercício é de trinta segundos e deve ser repetida três vezes para cada membro.

\begin{abstract}
Pescogo outro braço esticado e com a mão em extensão.

Ombro

Puxar com uma das mãos o cotovelo até sentir alongar a região posterior do ombro.
\end{abstract}

Ficar na posiçăo sentada, sem encostar a coluna, mantendo-a reta, inclinar a cabeça para o lado puxando-a com uma das mãos, manter

Extensores de punho 
Manter um dos braços estendidos, dobrar o punho para baixo com o auxilio da outra mão, repetir o mesmo com a outra mão

Flexionar o polegar e segurá-lo com os dedos e realizar um movimento de desvio para baixo.

Palme de mato e dedos

Manter os cotovelos flexionados e abertos, colocar as pontas de dedos juntas e o polegar em oposiçåo aos outros dedos, apertar as mãos, para sentir esticar os dedos e a palma das mão.

Este texto foi extra ido do site hittp /lopenlink.br.inter.net/ruicastro/ visite este site e saiba mito mais... 
Anexo K

Dinâmica de grupo: Rabo do Burro

Objetivo:

Identificar as intercorrências do planejamento em grupo; identificar a relação entre técnicas e o planejamento; identificar as fases no processo de planejamento.

Instrução:

O palestrante deverá solicitar aos participantes que se dividam em quatro ou seis grupos. Cada grupo deverá eleger um representante.

A regra do jogo é que os representantes dos grupos, ao mesmo tempo e de olhos vendados, preguem o rabo no burro. O cartaz com o desenho do burro deve ser afixado num extremo da sala, no outro extremo, deverá ser traçada uma linha no chão. Todos os grupos devem se colocar atrás da linha, que será a marca de saída para o jogo.

Cada grupo deverá receber uma venda e um rabo de papel de cores diferentes. O palestrante deverá dar alguns minutos para que os grupos combinem uma forma de orientar o seu representante sem passar da linha traçada no chão.

Terminado esse tempo, os representantes devem ser dispostos na linha, rodados uma ou duas vezes. O palestrante deverá dar o sinal de saída, fiscalizar o percurso e avisar aos representantes que tirem a venda assim que pregarem o rabo, onde quer que seja. 
Assim que todos representantes pregarem os rabos, o palestrante deve verificar quem conseguiu fixar o rabo mais próximo do local correto e assinalar com $X$ no desenho do burro.

Podem ser feitas tantas rodadas quantas se julgar necessário, desde que em cada rodada se troque o representante.

Material necessário: Um cartaz grande com o desenho do burro, rabos de papel de cores diferentes (um para cada grupo), fita crepe para fazer rolinhos para grudar os rabos.

Discussão:

O que facilitou e/ou dificultou o desempenho de cada grupo?

Como cada grupo planejou a orientação de seu representante? Foi possível executá-la?

Algum dos representantes conseguiu se orientar pelas dicas do grupo?

Os grupos se atrapalharam entre si e por que?

Qual a relação entre o que aconteceu no jogo e a atividade de planejamento e escolha de técnicas?

Como as intercorrências que aconteceram no jogo são no dia-a-dia entre os grupos no trabalho? 
Anexo L

Dinâmica de Grupo: A Linha da Vida

Objetivo:

Reconstituir o histórico de um lugar ou processo.

Instruções:

Aspecto histórico a recuperar com o grupo: Tema TRABALHO

- O trabalho que eu aprendi a fazer

- $\quad$ O trabalho que eu gostaria ter aprendido

- O trabalho que eu desenvolvo

- O trabalho que eu gostaria de desenvolver

O palestrante deverá confeccionar a matriz da linha da vida. Sugere-se utilizar papel manilha pardo, devido a baixo custo e à resistência. Sugere-se que o papel a ser trabalhado cada um dos aspectos do tema tenha, no mínimo, um metro e meio de comprimento. A linha é constituída conforme o modelo que se segue:

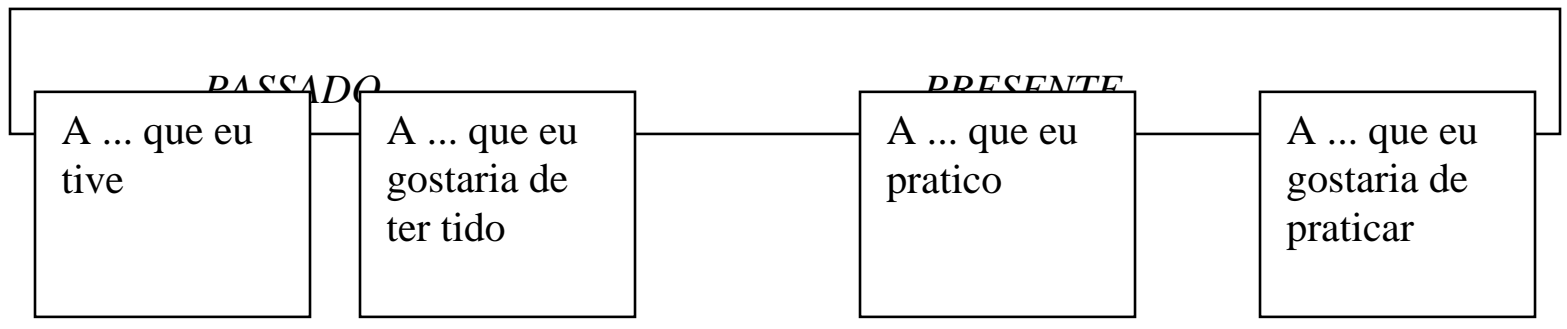


A técnica consiste, basicamente, na elaboração de murais em grupos, sobre cada um dos aspectos abordados na linha. Para aplicação, divide-se a técnica em duas partes.

\section{ETAPA INDIVIDUAL:}

O palestrante deverá providenciar quatro caixas vazias. Nela deverá afixar um papel onde estarão escritos as fases da linha da vida, um em cada caixa.

Deverá também providenciar material para que sejam feitos os murais. Poderão ser utilizados recortes de papel colorido, recortes de revista, lápis de cor ou pincel para que sejam feitos desenhos individuais, etc..

O palestrante deve solicitar aos participantes que observem cada uma das fases afixadas nas caixas. Cada participante deverá escolher ou produzir um material que melhor expresse sua vivência/percepção de cada uma das quatro fases. Desta forma, cada participante selecionará quatro materiais ou produzirá quatro desenhos. Os materiais/desenhos deverão ser colocados na caixa correspondente à fase.

\section{ETAPA COLETIVA:}

O palestrante deverá solicitar aos participantes que se dividam em quatro grupos. Cada grupo receberá a caixa correspondente a uma fase e um pedaço da linha da vida daquela mesma fase.

O palestrante deverá orientar aos participantes para que produzam um mural que expresse a vivência/percepção coletivo do tema. Para isto deverão utilizar o material selecionado/produzido por todos os participantes e que se encontra na caixa que o grupo recebeu. Outras coisas poderão ser adicionadas, porém nenhum material poderá ser retirado.

Terminado os murais de cada grupo, o palestrante deve compor a linha completa, afixando a base de cada um dos murais na parede. Cada grupo deverá apresentar o seu pedaço da linha da vida. Deverá ser aberta plenária e discussão.

Dicas: 
- Por ser uma técnica relativamente longa, é recomendável que o monitor delimite tempo para a fase individual, coletiva e plenária.

- $\quad$ No caso de utilizar desenhos individuais, reforçar que não importa o aspecto estético do desenho e sim o significado para quem o produziu.

- As apresentações dos grupos ficam mais enriquecidas se, antes do próprio grupo apresentar seu mural, o palestrante solicitar que os demais participantes interpretem o que o grupo procurou transmitir.

Essa técnica é bastante produtiva para se fazer uma síntese coletiva a respeito de uma tema já trabalhado anteriormente, ou para diagnosticar como trabalham ou vivenciaram o tema. 


\section{Referências Bibliográficas}

ASSOCIAÇÃO BRASILEIRA DAS EMPRESAS DE REFEIÇÕES COLETIVA. Manual da ABERC de práticas de elaboração e serviço de refeições para coletividade. 4.ed., São Paulo: ABERC, 1998. 195p.

ASTETE, Martin W., GIAMPAOLI, E., ZIDAN, L. N., Riscos físicos. São Paulo: FUNDACENTRO, 1994. 112p.

BARBOSA FILHO, A N., Segurança no Trabalho \& Gestão Ambiental, 2001. $157 p$.

BRASIL, Consolidação das Leis de Trabalho. Org. OLIVEIRA, j., 17.ed.São Paulo: Saraiva, 1994.

BRASIL, Ministério da Saúde. Diagnóstico, tratamento, reabilitação, prevenção e fisiopatologia das LER/DORT. Brasília, 2001.

BRASIL, Ministério da Saúde. LER/DORT dilemas, polêmicas e dúvidas. Brasília, 2001.

BRASIL, Ministério da Saúde. Lesões por esforços repetitivos (LER) Distúrbios osteomusculares relacionados ao trabalho (DORT). Brasília, 2001.

BRASIL, Ministério da Saúde. Saber LER para prevenir DORT. Brasília, 2001. CAMPOS, José $L D$, Os novos rumos da perícia médica em acidente de trabalho. Revista Cipa, 40, 2001.

CASAROTTO, R. A, MENDES, F. L., Avaliação ergonômica de restaurantes. Anais de $4^{\circ}$ Congresso Latino Americano de Ergonomia e $8^{\circ}$ Congresso Brasileiro de Ergonomia. Florianópolis, 316-321, 1997.

CHAMMA, L., FORASTIERI, N., Análise das notificações de acidentes de trabalho e doenças ocupacionais em restaurantes ao longo de dez anos. Anais do XV Congresso Mundial Sobre Segurança no Trabalho. São Paulo, 1999. 
DUL, J., WEERDMEESTER, B., Ergonomia prática. São Paulo: Edgard Blucher, 1993.

FERREIRA, Leda L, Enxugamento de pessoal e intensificação do trabalho: um problema para a segurança e saúde dos trabalhadores. Revista Cipa, 76-77, 2001.

GRADJEAN, E., Manual de Ergonomia adaptando o trabalho ao homem. 4 ed., Porto Alegre: Bookman, 1998.338p.

HASLEGRAVE, C. M. What do we mean by a working posture?. Ergonomics. v.37, 781-799, 1994.

HIBA, J. C., Cuando la pequeña quiere. Madrid: Instituto Nacional de Seguridad e Higiene em el Trabajo, 1997, 197p.

KANAPIS, A L., O ambiente de trabalho nos serviços de alimentação e nutrição. Revista Alimentação e Nuttrição. V.23, 31-35, 1986.

KINTON, R., CESERANI, V., FOSKETT, D, Enciclopédia de serviços de alimentação. São Paulo: Varella, 1999. 703p.

LAIGLE, F., LÉONARD, R., TEUWEN, E., HALLOT, R., Conception ergonomique d'une unité de restauration collective, Arch. Mal. Prof, n.4, 215-218, 1988.

LAVILLE, A, Ergonomia. São Paulo: EPU, 1977.99p.

LAWSON, M. P., Diseño de establecimentos alimentarios. Barcelona: Blume, 1978. 144p.

LEMOS, M. P., Contribuições da ergonomia na melhoria da qualidade higiênico-sanitária de refeições coletivas: um estudo de caso. Floaanópolis, Dissertação de Mestrado. Universidade Federal de Santa Catarina, 1999.

LIDA, I., Ergonomia projeto e produção. São Paulo: Edgard Bllucher , 1990. $465 p$. 
MATOS, C. H., Condições de trabalho e estado nutricional de operadores do setor de alimentação coletiva: um estudo de caso. Florianópolis, Dissertação de Mestrado. Universidade Federal de Santa Catarina, 2000.

MONTEIRO, J.C., SANTANA, A. M. C., DUARTE, M.F.S. et al., Análise de posturas no trabalho para entender a performance física do trabalhador do setor de carnes do restaurante universitário da UFSC. Anais do $4^{\circ}$ Congresso Latino Americano de Ergonomia e $8^{\circ}$ Congresso Brasileiro de Ergonomia. Florianópolis, 1997.

OKAMOTO, V. a, SANTOS, U. P., Ruído riscos e prevenção, São Paulo: Hucitec, 1994.

PASTORE, José, Acidentes do trabalho: só custos nenhum benefício. Revista Cipa, 58 - 61, 2001.

PIZA, Fábio $\mathrm{T}$, Como criar e desenvolver hábitos de trabalho corretos. Revista Cipa, 32, 2001.

PIZA, Fábio T., A arte de aprender um novo hábito. Revista Cipa, 88 - 91, 2201.

PIZA, Fábio T, Informações básicas sobre saúde e segurança no trabalho. São Paulo: CIPA, 1997. 115p.

ROSA, Jorge L, Insalubridade, penosidade e ergonomia. Revista Cipa, 9295, 2001.

SANTANA, A M. C. S., A abordagem ergonômica como proposta para melhoria do trabalho e produtividade em serviços de alimentação, Dissertação (Mestrado em Engenharia de Produção) UFSC, Florianópolis, 1996.

Secretaria de Estado da Saúde. Educação em saúde coletânea de técnicas. São Paulo,1993.

SCHVARTSMAN, Samuel, Produtos químicos de uso domiciliar. São Paulo, 1988. 
SILVA FILHO, A R., Manual básico para planejamento e projeto de restaurantes e cozinhas industriais, São Paulo: Varella, 1996.232p.

SILVA Jr., Eneo A, Manual de Controle Higiênico-Sanitário em Alimentos. 4.ed., São Paulo: Varella, 2001.475p.

SOUSA, A A, FELIPE, M. R., SALES, R. K. L., TOSIN, I., Análise de Perigos e Pontos Críticos de Controle (HACCP), Hospital Maternidade Carmela Dutra (HMCD), Relatório Final. Florianópolis: NTR/UFSC, 1997.

SINOTTI, Adjar A, Ainda a responsabilidade do empregador para as doenças profissionais: subjetiva ou objetiva?. Revista Cipa, 2001.

TEIXEIRA, S. M. F., OliVEIRA, Z. M. C., REGO, J. C., BISCONTI, T. M. B., Administração aplicada às Unidades de Alimentação e Nutrição. São Paulo: Atheneu, 1990.

TORREIRA, Raul P, Riscos biológicos. Revista Cipa, 40-41, 2001.

USSAN, Sérgio, Relação equipamento de proteção individual e certificado de aprovação funciona?. Revista Cipa, 42, 2001.

VOLPI, Sylvia, DORT: inegável sua existência. Revista Cipa, 28, 2001.

VOLPI, Sylvia, Prevenir os DORT por meio de medidas ergonômicas. Revista Cipa, 34, 2001. 
